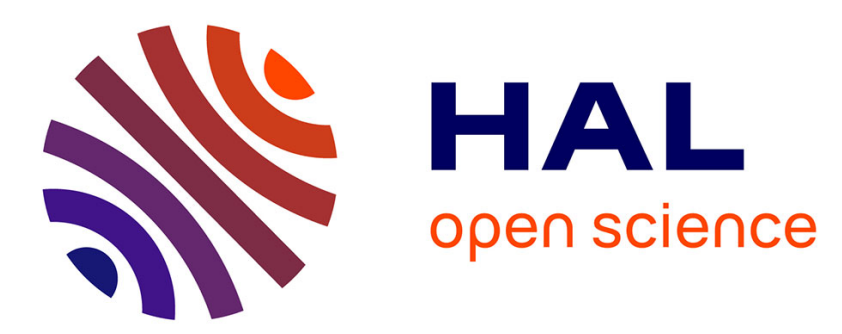

\title{
Contrasting genetic diversity patterns in two sister kelp species co-distributed along the coast of Brittany, France
}

Marine Robuchon, Line Le Gall, Stéphane Mauger, Myriam Valero

\section{To cite this version:}

Marine Robuchon, Line Le Gall, Stéphane Mauger, Myriam Valero. Contrasting genetic diversity patterns in two sister kelp species co-distributed along the coast of Brittany, France. Molecular Ecology, 2014, 23 (11), pp.2669-2685. 10.1111/mec.12774 . hal-01138773

\section{HAL Id: hal-01138773 \\ https://hal.science/hal-01138773}

Submitted on 17 Apr 2015

HAL is a multi-disciplinary open access archive for the deposit and dissemination of scientific research documents, whether they are published or not. The documents may come from teaching and research institutions in France or abroad, or from public or private research centers.
L'archive ouverte pluridisciplinaire HAL, est destinée au dépôt et à la diffusion de documents scientifiques de niveau recherche, publiés ou non, émanant des établissements d'enseignement et de recherche français ou étrangers, des laboratoires publics ou privés. 
Received Date : 06-Jan-2014

Revised Date : 04-Apr-2014

Accepted Date : 09-Apr-2014

Article type : Original Article

\section{Contrasting genetic diversity patterns in two sister kelp species co-distributed along the coast of Brittany, France}

Marine Robuchon ${ }^{123^{*}}$, Line Le Gall ${ }^{1}$, Stéphane Mauger ${ }^{23 \mu}$ and Myriam Valero ${ }^{23 \mu *}$

${ }^{1}$ ISYEB Institut, UMR 7205 CNRS-EPHE-MNHN-UPMC, Equipe Exploration, Espèces et Evolution, Muséum National d'Histoire Naturelle, case postale $\mathrm{N}^{\circ}$ 39, 57 rue Cuvier, 75231 Cedex 05 Paris, France

${ }^{2}$ CNRS, UMR 7144 Adaptation et Diversité en Milieu Marin, Equipe BEDIM, Station Biologique de Roscoff, CS 90074, 29688 Roscoff, France

${ }^{3}$ Sorbonne Universités, UPMC Univ Paris 06, UMR 7144 Adaptation et Diversité en Milieu Marin, Equipe BEDIM, Station Biologique de Roscoff, CS 90074, 29688 Roscoff, France

${ }^{\mu}$ Current address: UMI 3604 Evolutionary Biology and Ecology of Algae, CNRS, UPMC, Station Biologique de Roscoff, CS 90074, 29688 Roscoff, France

Keywords: distribution width, genetic structure, marginal populations, range edge, seaweeds, tidal height

This article has been accepted for publication and undergone full peer review but has not been through the copyediting, typesetting, pagination and proofreading process, which may lead to differences between this version and the Version of Record. Please cite this article as doi: $10.1111 / \mathrm{mec} .12774$

This article is protected by copyright. All rights reserved. 
* Corresponding authors: marine.robuchon@gmail.com, +336 77405460 and myriam.valero@sb-roscoff.fr, +33298292328

Running title: Genetic diversity in two sister kelp species

\section{Abstract}

We investigated patterns of genetic structure in two sister kelp species to explore how distribution width along the shore, zonation, latitudinal distribution and historical factors contribute to contrasting patterns of genetic diversity. We implemented a hierarchical sampling scheme to compare patterns of genetic diversity and structure in these two kelp species co-distributed along the coasts of Brittany (France) using a total of 12 microsatellites, 9 for Laminaria hyperborea and 11 for Laminaria digitata, of which 8 amplified in both species. The genetic diversity and connectivity of $L$. hyperborea populations was greater than that of $L$. digitata populations in accordance with the larger cross-shore distribution width along the coast and the greater depth occupied by L. hyperborea populations in contrast to $L$. digitata populations. In addition, marginal populations showed reduced genetic diversity and connectivity, which erased isolation-by-distance patterns in both species. As L. digitata encounters its southern range limit in southern Brittany while L. hyperborea extends down to mid-Portugal, it was possible to distinguish the effect of habitat continuity from range edge effects. We found that $L$. digitata did not harbour high regional diversity at its southern edge, as expected in a typical rear edge, suggesting that refuges from the last glacial maximum for L. digitata were probably not located in southern Brittany, but most likely further north. For both species, the highest levels of genetic diversity were found in the Iroise Sea and Morlaix Bay, the two regions in which they are being currently harvested. Preserving genetic diversity 
of these two foundation species in these areas should, thus, be a priority for the management of this resource in Brittany.

\section{Introduction}

The effect of spatial structure on genetic diversity and the consequences of small population size have been widely investigated (Mc Cauley 1991; Charlesworth et al. 2003; Walser \& Haag 2012), particularly in the field of conservation genetics, because of their potential effect on the survival of populations and species (Frankel \& Soulé 1981). In his pioneering article describing the phenomenon of isolation by distance (IBD) in continuously distributed populations, Wright (1943) predicted that a species whose range is essentially linear should show more genetic structure than a species whose range is two-dimensional. This difference in structure results in increased variability in gene frequencies among generations in linearly arranged populations compared to populations that are arranged in two dimensions.

Furthermore, more recent theoretical approaches (Rousset 1997; Barton et al. 2013), have confirmed Wright's prediction that species distributed in a linear fashion should show more differentiation than those spreading in two dimensions.

In addition to the intuitive result that genetic divergence increases with distance, the model of Wilkins and Wakeley (2002), based on the assumption of a finite continuous habitat (e.g. along a stretch of coastline) with realistic treatments of habitat boundaries, predicts that genetic diversity will be at its greatest near the centre of a species distribution. However, species are not always continuously distributed and may have fragmented populations at different locations within their range, particularly in peripheral populations located at range

edges. Thus, population genetic structure is predicted to vary along the geographic range of a

This article is protected by copyright. All rights reserved. 
species' distribution (Vucetich \& Waite 2003; Bridle \& Vines 2007). The 'abundant-centre' or 'central-marginal' model of species distributions predicts that peripheral populations exhibit lower genetic diversity and greater genetic differentiation relative to central populations (Eckert et al. 2008). Nevertheless, historical factors have been shown to interact with central-marginal trends and shape latitudinal patterns of genetic diversity across species' ranges (Guo 2012). In particular, populations occurring at rear edges (i.e. low latitude edges) are often located in areas that were refugia during the last glacial maximum and are, therefore, expected to retain high and unique genetic diversity compared to high latitude populations (Hewitt 1996; Ibrahim et al. 1996). Together with central-marginal trends, these predictions indicate that rear-edge populations should exhibit high differentiation, low within-population diversity but high and unique regional diversity (Hampe \& Petit 2005). Despite the large number of empirical studies testing range-wide genetic diversity patterns (for review, see Guo 2012 and references therein), the effect of distribution width (i.e. one-dimensional versus twodimensional distribution and the entire gradient between these two extremes, according to dimension widths) early predicted by Wright (1943) on genetic structure remains surprisingly little investigated.

Nearshore marine organisms are distributed linearly along the coast; however, the width of the band they occupy may differ between intertidal and subtidal species. For example, intertidal species are often distributed in narrow bands while subtidal species, particularly in areas where the slope of the continental shelf is weak, may occupy wider, relatively more two-dimensional bands (e.g. seagrass meadows and kelp forests). Nevertheless, in addition to the influence of distribution width, patterns of genetic differentiation in intertidal versus subtidal organisms may also result from the combination of other factors. Among the studies comparing levels of genetic differentiation in coastal

This article is protected by copyright. All rights reserved. 
organisms at several tidal heights (Engel et al. 2004; Marko 2004; Kelly \& Palumbi 2010; Valero et al. 2011; Krueger-Hadfield et al. 2013), most have revealed decreasing differentiation with decreasing tidal height and have explained this pattern either by differences in immersion time among organisms located at different tidal heights or differences in selective pressure along the tidal height gradient. However, to our knowledge, the hypothesis regarding the influence of distribution width has never been suggested as a putative explanation of the contrasted connectivity patterns observed across different tidal heights.

The geography of Brittany's coastline results from the erosion of the metamorphic and magmatic rocks that make up the Armorican Massif, and therefore most of its shores are rocky. This area harbours a high diversity of seaweed species (Kerswell 2006), including two emblematic kelp species: Laminaria digitata (Hudson) J.V. Lamouroux and Laminaria hyperborea (Gunnerus) Foslie. These foundation species form large underwater forests that play an essential ecological role by providing habitat, protection and food to numerous organisms (Lobban \& Harrison 1994; Steneck et al. 2002). However, kelp-dominated habitats in the North-East Atlantic have not been studied as much as those in other regions such as Australia and North America in the past few decades (reviewed by Smale et al. 2013). Laminaria digitata $(L d)$ and L. hyperborea $(L h)$ are two sister species (McDevit \& Saunders 2010) that have similar overall gross morphology, consisting of a large blade atop an elongated, stem-like stipe (however, the stipe is more flexible in $L d$ than in $L h$ ). Both species have the same life cycle in which a macroscopic sporophyte (diploid) alternates with a microscopic gametophyte (haploid). Furthermore, both species are currently harvested in Brittany for their alginate content. Populations of $L d$ are usually distributed in a narrow, linear band along the coast spanning the lower intertidal and upper subtidal zones, whereas

This article is protected by copyright. All rights reserved. 
populations of $L h$ are distributed in a wider band, sometimes even forming vast stands stretching across the subtidal zone (reviewed by Birkett et al. 1998; but see Hop et al. 2012). Along the European coastline, both species overlap for most of their geographic range; however, the northern-most species $L d$ encounters its southern range limit in southern Brittany while Lh extends southward to mid-Portugal (Kain 1971; Lüning 1990).

In light of the contrasting characteristics of the closely related kelp species $L d$ and $L h$, two hypotheses can be formulated regarding the differences expected in their genetic patterns. First, because populations of $L h$ are distributed in a wider band than those of $L d$ and located at a lower tidal height than those of $L d$, they should be more connected with higher levels of genetic diversity. Second, the genetic diversity and structure of $L h$ populations in southern Brittany should not differ from that of its other populations whereas $L d$ populations in this area should harbour higher differentiation, reduced local genetic diversity and high and unique regional genetic diversity compared to the other areas of the study, because southern Brittany is the rear edge of $L d$ 's species distribution.

In this study, we implemented a hierarchical sampling design, sampling kelp populations in 21 sites across $500 \mathrm{~km}$ of the Brittany coast, to characterise the patterns of genetic diversity and structure in $L d$ and $L h$ using microsatellites and to test the aforementioned hypotheses.

This article is protected by copyright. All rights reserved. 


\section{Materials and methods}

\section{Sampling design and study area}

To investigate the patterns of genetic diversity and genetic structure occurring among populations of the kelps Laminaria digitata and L. hyperborea, whose characteristics are summarised in Fig. 1, a hierarchical sampling design was implemented. Three spatial levels were considered: (1) regions separated by $60-180 \mathrm{~km}$, (2) localities separated by $10-15 \mathrm{~km}$ and (3) sites separated by 300-1000 m (Fig. 2a). Four regions were included in the study: St Malo Bay (SMB), Morlaix Bay (MoB), Iroise Sea (IrS) and southern Brittany (SBr), all located in Brittany (north-western France, Fig. 2b). In MoB and IrS, which are in the centre of the rocky shore continuum along the Brittany coastline, four localities, each consisting of one or two sites, were sampled. St Malo Bay is separated from this central rocky continuum by a long sandy beach; therefore, populations of both species in SMB can be considered as marginal/peripheral in terms of habitat continuity. $\mathrm{SBr}$, which has a continuous rocky shore, represents the southern edge of the species range for $L d$; therefore, in this region, populations of $L d$ can be considered as marginal in terms of species range, but not those of $L h$ which extend $80 \mathrm{~km}$ further south (Fig. 1). Within SMB and SBr, three localities, each one consisting of one or two sites, were sampled. In total, 21 sites were sampled; all GPS coordinates are given in Table1.

\section{Tissue collection and DNA extraction}

The objective was to collect a minimum of 30 sporophytes by site and by species, chosen at random among the individual sporophytes exceeding $30 \mathrm{~cm}$ size. However, in three sites (Guimereux, Nerput and St Mathieu) with low density, fewer than $30 L d$ sporophytes were sampled. Tissue samples consisting of a small disc of tissue at the base of the blade (a non-

This article is protected by copyright. All rights reserved. 
lethal procedure) were sampled from $829 L d$ and $1057 L h$ sporophytes, generally by scuba diving. At each site, both species were sampled except in Ile Téviec where wave conditions were too dangerous to collect $L d$. Tissue samples were preserved in individual plastic bags containing silica gel and stored at room temperature. DNA extraction was performed on 5-10 mg of dried tissue using the NucleoSpin ${ }^{\circledR} 96$ Plant II kit (Macherey-Nagel, GmbH \& Co. KG, Düren, Germany) following the manufacturer's instructions, except for the lysis step during which samples were left at room temperature for $1 \mathrm{~h}$ rather than heating to $65^{\circ} \mathrm{C}$ for $30 \mathrm{~min}$ and the elution step which was performed in $100 \mu \mathrm{L}$ rather than $200 \mu \mathrm{L}$ elution buffer.

\section{Microsatellite amplification, scoring and correction}

Six microsatellites previously developed for $L d(\operatorname{Ld} 148, \operatorname{Ld} 158, \operatorname{Ld} 167, \operatorname{Ld} 371, \operatorname{Ld} 531$ and Ld704) (Billot et al. 1998) and seven additional ones developed for Laminaria ochroleuca (Lo4-24, Lo454-15, Lo454-17, Lo454-23, Lo454-24, Lo454-27 and Lo454-28) (Coelho et al. pers. comm.) were used. For $L d, 12$ microsatellites were amplified by PCR in four different multiplex mixes MM1 (Ld148, Ld158, Ld167, Ld371, Ld531 and Ld704), MM2 (Lo454-23, Lo454-24 and Lo454-27), MM3 (Lo454-17 and Lo454-28) and MM4 (Lo4-24). For Lh, 11 microsatellites were amplified in three different mixes: MM1 (Ld148, Ld158, Ld167, Ld371, Ld531 and Ld704), MM5 (Lo454-15, Lo454-17, and Lo454-28) and MM6 (Lo454-23 and Lo454-24). Multiplex PCRs were performed, amplifying several loci simultaneously, using a PT-200 thermocycler (MJ Research, Waltham, MA, USA) in $10 \mu \mathrm{L}$ final volume containing 1X GoTaq ${ }^{\circledR}$ Flexi colourless reaction buffer (Promega Corp., Madison, WI, USA), 2 mM $\mathrm{MgCl}_{2}, 150 \mu \mathrm{M}$ dNTPs, $0.35 \mathrm{U}$ GoTaq ${ }^{\circledR}$ DNA polymerase (Promega Corp.) and $2 \mu \mathrm{L}$ of template DNA (diluted to 1:100). Primers, primer concentrations and amplification conditions differed according to the multiplex mix. For MM1, primer concentrations were $100 \mathrm{nM}$ for Ld148, Ld167 and Ld371, $150 \mathrm{nM}$ for Ld158 and $200 \mathrm{nM}$ for Ld531 and Ld704. For MM2 to

This article is protected by copyright. All rights reserved. 
MM6, all primer concentrations were 200 nM. For MM1, the PCR programme included an initial denaturation at $94{ }^{\circ} \mathrm{C}$ for 5 min, 5 cycles of a touchdown PCR (denaturation at $94{ }^{\circ} \mathrm{C}$ for $45 \mathrm{~s}$, annealing at $60^{\circ} \mathrm{C}$ for $1 \mathrm{~min}$ and extension at $72{ }^{\circ} \mathrm{C}$ for $45 \mathrm{~s} ; 1^{\circ} \mathrm{C}$ decrease of the annealing temperature every cycle), followed by 30 cycles of denaturation at $94{ }^{\circ} \mathrm{C}$ for $45 \mathrm{~s}$, annealing at $55^{\circ} \mathrm{C}$ for $45 \mathrm{~s}$ and extension at $72{ }^{\circ} \mathrm{C}$ for $1 \mathrm{~min}$ and a final extension at $72^{\circ} \mathrm{C}$ for 30 min. For MM2, MM3, MM5 and MM6, the PCR program included an initial denaturation at $94{ }^{\circ} \mathrm{C}$ for $5 \mathrm{~min}, 35$ cycles of denaturation at $94{ }^{\circ} \mathrm{C}$ for $30 \mathrm{~s}$, annealing at $60{ }^{\circ} \mathrm{C}$ for $30 \mathrm{~s}$ and extension at $72{ }^{\circ} \mathrm{C}$ for $45 \mathrm{~s}$ and a final extension at $72{ }^{\circ} \mathrm{C}$ for $20 \mathrm{~min}$. These latter conditions were similar for MM4 except the annealing temperature which was $50{ }^{\circ} \mathrm{C}$. Forward primers were fluorescently labelled with 6-FAM (Ld531, Lo454-15 and Lo454-24), NED (Ld158, Ld371, Lo454-23 and Lo454-28), PET (Ld148, Ld704, Lo4-24 and Lo454-27) or VIC (Ld167 and Lo454-17) dye (Applied Biosystems, Foster City, CA, USA). The loading mix for sizing was prepared by adding $2 \mu \mathrm{L}$ of each PCR product to $10 \mu \mathrm{L}$ of loading buffer containing 0.5 $\mu \mathrm{L}$ of the SM594 size standard (Mauger et al. 2012) plus $9.5 \mu \mathrm{L}$ of Hi-Di formamide (Applied Biosystems). This loading mix was denatured at $94{ }^{\circ} \mathrm{C}$ for $5 \mathrm{~min}$ and run in an $\mathrm{ABI}$ 3130 xl capillary sequencer (Applied Biosystems) equipped with $50 \mathrm{~cm}$ capillaries.

Alleles were scored manually using the software GeneMapper® version 4.0 (Applied Biosystems). After two re-amplifications, individuals for which more than one locus did not amplify correctly were removed from the dataset. Loci were tested for null alleles and scoring errors using MICRO-CHECKER software version 2.2.3 (van Oosterhout et al. 2004). Linkage disequilibrium between pairs of loci was computed with FSTAT (Goudet 2001). The number of repeated multilocus genotypes at each site was calculated using GENALEX 6.5 (Peakall \& Smouse 2012) and the genotypic diversity $R$ was computed as the number of distinct

This article is protected by copyright. All rights reserved. 
genotypes $(G) /$ number of individuals and corrected for sample size $(R=G-1 / N-1$, Dorken $\&$ Eckert 2001)

\section{Genetic diversity}

Standard measures of genetic diversity (mean number of alleles per locus $\left(N_{\mathrm{a}}\right)$, unbiased expected heterozygosity $\left(H_{\mathrm{e}}\right.$; Nei 1987), allelic richness (AR) rarefied to 19 individuals) were calculated at each site using FSTAT (Goudet 2001). Allelic richness by site was not calculated for the sites Guimereux, Nerput and St Mathieu because the $L d$ sample size was too small. Additionally, these three estimates of genetic diversity were calculated for each region by pooling sites within a region, and AR was rarefied to 132 individuals. The number of private alleles $\left(P_{\mathrm{a}}\right)$ per site and per region was calculated using GENALEX 6 (Peakall \& Smouse 2005). Permutational analyses of variance (PERMANOVA) were performed to test for effects of space ('region' or 'site'), species and their interaction on genetic diversity (AR and $H_{\mathrm{e}}$ ) using each couple site/locus as a repetition, on the basis of a Bray-Curtis distance matrix and with 9999 unrestricted permutations of raw data as our data did not fit the assumptions of normality and homogeneity of variance. Homogeneity of multivariate dispersion was also tested by inferring deviations from a centroid using a distance-based test. These analyses were carried out on a dataset restricted to the eight loci common to both species and the 17 sites where both species presented a number of individuals with complete genotypes $\geq 19$, using PRIMER 6 version 16.1.13 and PERMANOVA+ version 1.0.3 (Clarke \& Gorley 2006; Anderson et al. 2008). Finally, in each site, departure from random mating (inbreeding coefficient: $F_{\text {IS }}$ ) was tested using FSTAT (Goudet 2001) by permuting alleles among individuals within populations.

This article is protected by copyright. All rights reserved. 


\section{Genetic structure}

Pairwise $F_{\mathrm{ST}}$ (as defined by Weir \& Cockerham 1984) values were calculated for all site pairs within each species and, for each pairwise value, the significance of differentiation at the level of $5 \%$ was tested by permuting genotypes among sites using FSTAT (Goudet 2001). Overall genetic structure for both species was analysed using two complementary approaches. First, principal components analyses (PCA) based on allele frequencies were implemented in PCAGEN (Goudet 1999). Second, analyses of molecular variance (AMOVA) were carried out in Arlequin (Excoffier et al. 2005) with sites grouped into regions. Additionally, regional AMOVAs for each region were implemented with sites grouped into localities. Significance of the genetic structure was tested using 9999 permutations.

To perform tests of IBD, geographic distances between each pair of sites were calculated using the shortest path by the sea. IBD was tested for $L d$ and for $L h$, both over all populations and within each region, by implementing Mantel tests between a matrix of genetic distances $\left(F_{\mathrm{ST}} /\left(1-F_{\mathrm{ST}}\right)\right)$ and a matrix of geographic distances (in kilometres), using 1000 resamples. Since $L d$ and $L h$ have linear ranges, we used the untransformed geographic distances for both species, in accordance with Rousset (1997). Calculations of geographic distances and Mantel tests were performed in the free software R (R Development Core Team 2005), using the packages gdistance (van Etten 2012) and ncf (Bjørnstad 2009), respectively.

This article is protected by copyright. All rights reserved. 


\section{Results}

\section{Microsatellite amplification}

Allelic size profiles were unambiguous, and scoring was straightforward. All loci were polymorphic across all sites except Lo454-27 for $L d$ and Ld531 for $L h$; they were therefore removed from subsequent analyses. We did not detect any null alleles in $L d$ populations; however, Ld371 and Ld704 showed evidence of null alleles in $L h$ populations; these two loci were therefore eliminated from subsequent analyses. The final datasets consisted of 764 individuals genotyped at 10 to 11 loci for $L d$ (Table S1) and 1031 individuals genotyped at 8 to 9 loci for $L h$ (Table S2). No linkage disequilibrium between pairs of loci was detected in either species. For $L d$, only one site (Primel) showed significant departure from random mating $\left(F_{\text {IS }}=0.145\right.$, Table 1a), and none for $L h$ (Table1b). The efficiency of the microsatellite loci to discriminate among individuals was very high, with more than $80 \%$ of sites harbouring samples that consisted only of unique multilocus genotypes $(R=1)$ for both species $(16 / 20$ sites for $L d$ and $17 / 21$ sites for $L h$, Tables $2 \mathrm{a}$ and b, respectively). The lowest value of genotypic diversity was observed in Santec $(R=0.90)$ for $L d$ with four pairs of individuals sharing the same genotype and in Guimereux $(R=0.95)$ for $L h$ with two pairs of individuals sharing the same genotype.

\section{Patterns of genetic diversity along the Brittany coastline}

Multilocus genetic diversity estimates are shown in Table1a for $L d$ and in Table $1 \mathrm{~b}$ for $L h$ (details locus by locus are given in Tables $\mathrm{S} 3$ and $\mathrm{S} 4$, respectively). For $L d$, the number of alleles $\left(N_{\mathrm{a}}\right)$ ranged from 2.5 (SMB region) to 7.3 (IrS region). Rarefied allelic richness (AR) varied from 2.9 (SMB region) to 6.1 (IrS region). Expected heterozygosity varied between 0.349 (SMB region) and 0.624 (IrS region). Therefore, the sites with the lowest genetic

This article is protected by copyright. All rights reserved. 
diversity estimates were in SMB and those with the highest genetic diversity estimates in IrS. For $L h, N_{\mathrm{a}}$ ranged from 3.1 (SMB region) to 6.6 ( $\mathrm{SBr}$ region). AR varied from 2.9 (SMB region) to 5.2 (IrS region). $H_{\mathrm{e}}$ varied between 0.429 (SMB region) and 0.622 (IrS region). Therefore, as for $L d$, both AR and $H_{\mathrm{e}}$ showed their lowest values in SMB and their highest in IrS.

At the regional level, i.e. when individuals from all the sites within a region were pooled, the lowest AR and $H_{\mathrm{e}}$ values for $L d$ were observed in SMB and the highest in IrS. In contrast, for $L h$, while both $\mathrm{AR}$ and $H_{\mathrm{e}}$ were also at their lowest in SMB, the highest AR value was detected in $\mathrm{SBr}$ whereas $H_{\mathrm{e}}$ was highest in IrS. The lowest $P_{\mathrm{a}}$ value for $L d$ was found in $\mathrm{SBr}$ but in SMB for $L h$ and both species held their maximum $P_{\mathrm{a}}$ value in IrS.

Genetic diversity indices varied significantly both between species and geographically (i.e. across regions and across sites); however, different responses were obtained according to the diversity estimate (i.e. AR or $H_{\mathrm{e}}$, Table 2, Fig. 3). Multivariate dispersion was homogeneous among regions $(P=0.236)$, among sites $(P=0.902)$ and between species $(P=$ 0.439); therefore, the differences observed between the levels of these three factors were could be attributed to the factors tested and not to statistical bias in the distribution of the data.

The pattern of allelic richness varied significantly between species and across regions, and the interaction was significant (Table 2a, Fig. 2a). Allelic richness was globally higher in $L h$ (mean $\mathrm{AR} \pm$ standard error over sites $=4.6 \pm 0.1)$ than in $L d(4.2 \pm 0.2)$. For both species, AR was significantly lower in the SMB region and higher in the two central regions of MoB and IrS, whereas in $\mathrm{SBr}$, the pattern differed according to species, with AR being much higher in $L h$ than in $L d$ (Fig. 3a, see pairwise tests in Table S3). The same pattern was observed at the site level except that only the factor 'site' was significant (Fig. 3b, Table 2b).

This article is protected by copyright. All rights reserved. 
The pattern of gene diversity also varied significantly between species and across regions but the interaction between these factors was not significant (Table 2c). $H_{\mathrm{e}}$ was always higher in $L h$ (mean $H_{\mathrm{e}} \pm$ standard error over sites $\left.=0.570 \pm 0.013\right)$ than in $L d(0.488 \pm$ 0.019). For both species, $H_{\mathrm{e}}$ followed the same pattern across regions with lower values in SMB and higher values in the three other regions (Fig. 3c). At the site level, only the factor 'species' remained significant (Table $2 \mathrm{~d}$ ) with $L h$ showing higher $H_{\mathrm{e}}$ values than $L d$ at all sites (Fig. 3d).

\section{Patterns of genetic structure along the Brittany coastline}

Global analyses of genetic structure revealed significant genetic differentiation between most sites for $L d$ (153 out of 190 pairwise $F_{\mathrm{ST}}$ values, i.e. $81 \%$, Table S4), even at very small scales: the minimum distance for which significant differentiation was observed was less than $1 \mathrm{~km}$ (i.e. within SMB, between Nerput and Le Moulin). In contrast, fewer pairs of sites were significantly differentiated in $L h$ (138 out of 210 pairwise $F_{\mathrm{ST}}$ values, i.e. $66 \%$, Table S5) and the minimum distance for which a significant differentiation was observed was between 10 and $15 \mathrm{~km}$. Moreover, mean pairwise $F_{\mathrm{ST}}$ was lower in $L h$ (mean \pm standard error $0.085 \pm$ 0.006) than in $\operatorname{Ld}(0.094 \pm 0.005)$.

This difference between species regarding global genetic structure was confirmed by results of principal components analyses (PCA, Fig. 4). The first two axes explained $71.3 \%$ (resp. $86.2 \%$ ) of the total variance for $L d$ (resp. $L h$ ), the first axis explaining more than $50 \%$ in both species (53.5\% for $L d$ and $67.1 \%$ for $L h$ ). For both species, sites of SMB were separated from sites of $\mathrm{SBr}$ along the first axis and sites of MoB were close to the ones of IrS. However, for $L d$ sites of MoB were separated from the ones of IrS along the second axis (Fig. 4a) while these regions were inseparable for $\operatorname{Lh}$ (Fig. $4 b$ ).

This article is protected by copyright. All rights reserved. 
Hierarchical analyses of molecular variance revealed significant partitioning of genetic variation among regions and among localities within regions for $L d$ (Table 3a) and $L h$ (Table 3b). Although the amount of variation associated with the regional level was similar for both species ( 10\% of total variance), the variation associated with the partitioning among localities within regions was almost three times higher in $L d$ than in $L h$. Analyses of molecular variance within each region revealed contrasting patterns between species (Table 4). In MoB and IrS, patterns were similar for both species with a significant partitioning at the level of localities and a non-significant partitioning at the site level. This pattern was also observed for $L h$ in the two other regions; hence, partitioning did not differ among regions for this species (Table $4 b$ ). In contrast, for $L d$, partitioning at the level of localities was nonsignificant in SMB but significant at the site level and, in SBr, partitioning was significant at the locality and site levels (Table 4a).

There was a pattern of IBD in both species when examining all sites together (Fig. 5a, b); however, in $L d$, most genetic distances were proportional to geographic distance (Fig. 5a), in $L h$, for a given geographic distance, a large range of genetic distances was observed (Fig. $5 b)$. This variability was mainly due to the fact that sites of SMB were highly differentiated from sites of other regions, whatever their distance. Patterns of IBD within each of the four regions were consistent between species although they varied among regions (Fig. 5c, d): for both species, there was a significant IBD pattern in MoB and IrS but not in SMB or SBr. However, in $\mathrm{SBr}$, there were fewer comparisons (three and six comparisons for $L d$ and $L h$, respectively) than in the other regions, which probably affected the power of the statistical test.

This article is protected by copyright. All rights reserved. 


\section{Discussion}

As hypothesised, Laminaria digitata $(L d)$ and Laminaria hyperborea $(L h)$ displayed distinct patterns of genetic diversity and structure, with populations of $L h$ being more diverse and more connected than those of $L d$ (Table1, Figs. $2 \& 3$ ). The comparison of the genetic diversity patterns between these two sister species can be used to discuss how distribution width, tidal height, latitudinal distribution and historical factors can lead to contrasting patterns of genetic diversity.

\section{Differences in minimum dispersal scale}

Laminaria digitata and L. hyperborea exhibit quite restricted dispersal, within the range of what has been reported for most macroalgal species (Santelices 1990; Kinlan et al. 2005). The significant partitioning of molecular variance among and within regions revealed that gene flow is reduced and populations are differentiated (Tables $4 \& 5$ ) at the scale of 10-15 km in both kelp species (and even at a scale of less than $1 \mathrm{~km}$ in $L d$ ). The minimum dispersal scale estimated in this study is similar to the values reported in a review of seven kelp species, including Ld (Valero et al. 2011).

\section{The linear costal habitat favours isolation by distance in Brittany for both kelp species}

Our study provided evidence of isolation by distance (IBD) along the Brittany coast (500 km) for both kelp species (Fig. 5) in spite of recent studies that suggest that Euclidian distances may not be appropriate for modelling gene flow in the marine environment; natural selection, historical factors or models of oceanographic currents appear to better explain patterns of genetic structure in many marine species (for review, see Hedgecock et al. 2007; and more recent studies in whelks, White et al. 2010; in fucoids, Coleman \& Kelaher 2009 and in kelps, Alberto et al. 2010). In these species, genetic differentiation patterns reflect past disturbances

This article is protected by copyright. All rights reserved. 
rather than contemporary processes because the establishment of IBD patterns requires sufficient time and equilibriums are generally not reached. However, Kimura and Weiss (1964) have demonstrated that equilibrium should be reached faster along a linear stretch than in a two-dimensional area. In the present study, the relatively short distance dispersal and almost continuous distribution of two kelps species along the rocky shoreline of Brittany likely explain the fact that our data better fit an IBD pattern than populations of non-linearly distributed and fragmented marine organisms that are connected by larval dispersal for which non-visible oceanic barriers may occur. This hypothesis is supported by a recent review showing clear evidence of IBD across a multitude of macroalgal species (Durrant et al. in press).

Alternation of generations does not favour selfing in the two kelp species

Both $L d$ and $L h$ exhibit a typical kelp life-history with an alternation of free-living microscopic, haploid, male and female gametophytes with macroscopic diploid sporophyte; this type of life history has consequences on fertilisation success, recruitment and dispersal (see, for example, Reed 1990, Billot et al. 2003, Raimondi et al. 2004). The dispersal of male gametes is considered to be less than a few centimetres (see Reed 1990 for review) because a pioneering study (Lüning \& Muller 1978) demonstrated that male gametophytes release sperm in response to a pheromone produced by female gametophytes to guide the sperm to the non-motile egg. Furthermore, observations in the kelp species Macrocystis pyrifera and Pterygophora californica show that sporophyte recruitment depends mainly on meiospore density to ensure sperm-egg encounters (Reed 1990). Consequently, meiospore dilution is considered to be a major limitation in kelp dispersal distances. This may also favour selfing, especially when sporophyte density is low, even if high levels of inbreeding depression have been observed in M. pyrifera (Raimondi et al. 2004). In addition, spores of M. pyrifera are

This article is protected by copyright. All rights reserved. 
produced in sporangia that occur on specialised blades called sporophylls located near the base of the alga, further restricting dispersal. However, in $L d$ and $L h$, meiospores are produced on the blade, the distal portion of the plant, and are therefore released 1 to $3 \mathrm{~m}$ above the substratum at high tide, which may facilitate their transport in the water column. When released, spores are probably dispersed away from their parent sporophyte and related sibs. Kelp blades within the kelp forest may also act as paddles increasing water movement and consequently enhancing meiospore dispersal. Accordingly, no significant departure from random mating was observed within most sites for either species (Table1). In addition to localised dispersal, rare events of long-distance dispersal are also possible by fertile drifting blades that continue to produce and release meiospores, as shown in the giant kelp Macrocystis spp. (Macaya et al. 2005).

Differences in genetic structure between the two kelp species: life history traits versus spatial arrangement of populations

Although both species are perennial, $L h$ lives three times longer than $L d$. Several comparative studies (Hamrick \& Godt 1996; Nybom 2004) have reported that longer-lived species retain most of their genetic variability within populations and those with a shorter life span allocate most of their genetic variability among populations. Likewise, this pattern was observed in the present study. However, the effects of longer longevity on higher genetic diversity are not easy to explain and covariation between life span and dispersal mechanisms may introduce some biases to these comparative studies (Duminil et al. (2007).

The differences in spatial structure between the two sister species revealed in our study can be attributed to factors other than longevity, such as differences in the spatial arrangement of their populations: $L d$ occupies a narrow band in the low-intertidal zone while

This article is protected by copyright. All rights reserved. 
populations of $L h$ form a wide band in the high to mid-subtidal zone. Our results show that even for two species that are distributed along the coast, the width of the band might have an effect on spatial genetic structure: populations of $L h$ were more connected (i.e. less structured) than populations of $L d$ (Fig. 4). This pattern may also result from the influence of tidal height: several studies have reported a decrease in genetic structure with increasing tidal height (see for example the reviews based 50 nearshore marine invertebrate species in Kelly and Palumbi (2010) and on 17 kelp species in Valero et al. (2011)). There are two arguments that can explain this pattern. The first argument is that intertidal organisms spend less time immersed than subtidal ones and thus their propagules have less opportunity to disperse in the water column. The second argument is that intertidal species undergo a greater variety of environmental stresses than subtidal ones (Helmuth \& Hofmann 2001). In this stressful environment, selection may favour restricted dispersal (either via differential larval behaviour of fishes, Kelly \& Palumbi 2010; or selfing in seaweeds, Billard et al. 2010) to maintain local adaptation, and therefore indirectly affect genetic structure.

\section{Marginality of populations: limit of habitat continuity versus edge of distributional range}

Although $L h$ generally exhibited more genetic diversity and connectivity than its sister species (Figs. $2 \& 3$ ), patterns of genetic diversity and structure varied greatly among the regions studied (Table 2). Core populations located in the regions of MoB and IrS, inhabiting the centre of the continuous rocky habitat of the Brittany coast, harboured a typical pattern of large interconnected populations for both species (highest level of genetic diversity, lowest level of population structure and significant IBD). Moreover, north of SMB, Brittany is flanked by a large sandy stretch of coast (more than $20 \mathrm{~km}$ of sandy beach of the famous Mont Saint Michel Bay) unsuitable for settlement of either kelp species. In addition, the region of $\mathrm{SBr}$ corresponds to the southern edge of $L d$ 's distributional range, whereas $L h$ 's

This article is protected by copyright. All rights reserved. 
range extends down to Portugal. For both species, the typical pattern of fragmented marginal populations was found in the region of SMB (lower genetic diversity, increased genetic differentiation and no significant IBD). The fact that neither species showed significant IBD patterns in these marginal populations and only in core continuous populations (Fig. 5) suggests that these marginal populations are not at demographic equilibrium probably because they undergo regular and/or recent perturbations. These results confirm previous studies on $L d$ showing that marginal populations of SMB exhibit low genetic diversity as a result of habitat discontinuity in comparison to populations of MoB and IrS located within the continuum of rocky substratum (Billot et al. 2003; Valero et al. 2011; Couceiro et al. 2013). Examination of genetic samples collected over time in this species detected genetic changes only for the populations located in the region of SMB (Valero et al. 2011), confirming that these marginal populations are subject to recent demographic effects. Here, we demonstrated that, despite showing higher genetic diversity than its sister species, $L h$ is also affected by habitat discontinuity, hence reinforcing the importance of this factor in shaping kelp genetic patterns. This effect of habitat discontinuity leading to chaotic patterns of population genetic structure with weak relationships to inter-population distances has been demonstrated in several rocky shore species such as fishes (Riginos \& Nachman 2001; Watts \& Johnson 2004; Johansson et al. 2008), red macroalgae (Faugeron et al. 2001; Faugeron et al. 2004) and, in particular, kelps (Alberto et al. 2010; Fraser et al. 2010 and references therein).

Regarding the populations of the SBr region, genetic diversity remained high for $L h$ and comparable to core populations. In contrast, at the southern edge of its distributional range, $L d$ exhibited reduced within population genetic diversity. The reduced genetic diversity observed in $L d$ probably reflects the small size of populations due to their occurrence in suboptimal habitats. A recent study showed that higher temperatures affect sporulation in $L d$

This article is protected by copyright. All rights reserved. 
(Bartsch et al. 2013), which may contribute to meiotic dysfunction and the supposed occurrence of asexual reproduction observed in some populations of SBr. However, these populations were located around Belle-Île-en-Mer, i.e. slightly south of the populations of the present study (Oppliger 2010; Oppliger et al. submitted). We did not detect any patterns of asexual reproduction in our study: genotypic richness was not systematically lower in SBr. In addition, our study revealed that the pool of $L d$ populations in $\mathrm{SBr}$ exhibited neither high nor unique regional genetic diversity as expected according to the rear-edge hypothesis (Hampe \& Petit 2005). This hypothesis is based on the historical effect of the last glacial maximum and, therefore, it predicts that rear edges, because they often correspond to refuges from the last glacial maximum, should harbour high and unique regional diversity (Hewitt 1996; Ibrahim et al. 1996). In contrast to our findings and in accordance with the rear-edge hypothesis, field studies have highlighted that some species display high regional genetic diversity towards their rear edge. In the particular case of seaweeds and plants, several papers have been published recently showing this pattern of low levels of intra-population genetic diversity but high regional genetic diversity of pooled populations typical of rear edges along the European Atlantic coast (in the seagrass Zostera marina, Diekmann \& Serrão 2012; in the red alga Chondrus crispus, Provan \& Maggs 2012; and in the kelp Saccorhiza polyschides, Assis et al. 2013). In the case of $L d$, we contend that the populations in $\mathrm{SBr}$ do not constitute a long-term storage of genetic diversity as in classical rear edges. Refugia from the last glacial maximum for $L d$ were probably not located in $\mathrm{SBr}$, but most likely further north in the western part of the Channel (e.g. Hurd Deep) as reported for several macroalgae (Provan et al. 2005; Maggs et al. 2008). Moreover, for both $L d$ and $L h$, the highest levels of regional genetic diversity and unique diversity were found in the IrS and $\mathrm{MoB}$ (i.e. closer to the Hurd Deep) suggesting that this area sheltered refugia during the last glacial maximum.

This article is protected by copyright. All rights reserved. 


\section{Recommendations for the harvest and management of natural stocks}

In Brittany, $L d$ and $L h$ are both harvested to extract alginates and most of the crop comes from MoB and IrS, the two regions that store high and unique genetic diversity. On the one hand, the high genetic diversity of these two kelp species in MoB and the $\operatorname{IrS}$ ensure a high evolutionary potential for recovery despite harvesting. On the other hand, these populations harbour rare and unique genetic diversity, which is fragile: if lost, it is lost forever. In addition, $\mathrm{MoB}$ and the IrS have been described as potential refuges from recent climate change for several species of red seaweeds living under the kelp canopy (Gallon et al. submitted). To avoid the loss of rare genetic diversity and its potential negative effects at the community level (reviewed by Hughes et al. 2008), harvesting practices in Brittany should avoid fragmenting the kelp populations. Currently, $L h$ is harvesting using the Norwegian comb, a dragging device which scrapes the substratum leading to substantial breakage and crushing of its surface (pers. obs., L. Le Gall \& M. Robuchon). This substratum damage likely causes negative side-effects that have received little attention (Leclerc 2013) because most monitoring efforts are devoted to quotas. Although we do not have enough information yet to assess the impact of the Norwegian comb on the connectivity of $L h$ populations, it would be judicious to design a more efficient device to harvest $L h$ that will have less impact on the rocky substratum.

\section{Concluding remarks}

Our study provides empirical evidence to the prediction that a species whose distribution is essentially one dimensional shows more genetic structure than a species whose distribution tends to spread in two dimensions. This "distribution width effect" is probably an important factor shaping genetic diversity in a coastal habitat, which, together with other effects related

This article is protected by copyright. All rights reserved. 
to the location of species along a tidal height gradient (i.e., immersion time and selective pressure), predicts that intertidal species are less connected than subtidal species across the same shore. In addition, our study confirms that populations located at habitat discontinuities show reduced genetic diversity and connectivity. However, our results do not support the predictions of the rear-edge hypothesis because the regional genetic diversity at the southern limit of the species range (i.e., putative refugium) was not high, probably due to historical or demographic effects. Comparative studies in other nearshore marine species would be valuable to determine which aspects of species distributions exert the most influence on population genetic diversity and structure.

\section{Acknowledgements}

Funding was provided by grants from the natural marine park Parc Naturel Marin d'Iroise (convention CNRS-UPMC-PNMI, LS 64816) and from the French National Research Agency (ECOKELP ANR-06-BDIV-012 and IDEALG ANR-10-BTBR-04-02). M.R. received a PhD fellowship from the French Ministry for Higher Education and Research (Ministère de l'Enseignement Supérieur et de la Recherche). We warmly thank the marine operations department (Service Mer et Observation) of the Station biologique de Roscoff as well as the divers from the Centre de Recherche et d'Enseignement sur les Ecosystèmes Côtiers of Dinard and from the Parc Naturel Marin d'Iroise. We thank E. Serrão, F. Alberto and N. Coelho for providing the L. ochroleuca microsatellite primers. We are grateful to the Biogenouest Genomics core facility for its technical support. We thank C. Engel-Gautier for editing the manuscript and Christophe Destombe for his comments on the manuscript.

This article is protected by copyright. All rights reserved. 


\section{References}

Alberto F, Raimondi PT, Reed DC, et al. (2010) Habitat continuity and geographic distance predict population genetic differentiation in giant kelp. Ecology, 91, 49-56.

Anderson M, Gorley RN, Clarke RK (2008) Permanova+ for Primer: Guide to Software and Statistical Methods (ed. Laboratory PM), Plymouth, U.K.

Arzel P (1998) Les laminaires sur les côtes bretonnes. Evolution de l'exploitation et de la flottille de pêche, état actuel et perspectives. IFREMER, Plouzané, France. 139 pp.

Assis J, Coelho NC, Alberto F, et al. (2013) High and distinct range-edge genetic diversity despite local bottlenecks. PLoS ONE, 8, e68646.

Barton N, Etheridge A, Kelleher J, Véber A (2013) Genetic hitchhiking in spatially extended populations. Theoretical Population Biology, 87, 75-89.

Bartsch I, Wiencke C, Bischof K et al. (2008) The genus Laminaria sensu lato: recent insights and developments. European Journal of Phycology, 43, 1-86.

Bartsch I, Vogt J, Pehlke C, Hanelt D (2013) Prevailing sea surface temperatures inhibit summer reproduction of the kelp Laminaria digitata at Helgoland (North Sea). Journal of Phycology, 49, 1061-1073.

Billard E, Serrão E, Pearson G, Destombe C, Valero M (2010) Fucus vesiculosus and spiralis species complex: a nested model of local adaptation at the shore level. Marine Ecology Progress Series, 405, 163-174.

Billot C, Engel CR, Rousvoal S, Kloareg B, Valero M (2003) Current patterns, habitat discontinuities and population genetic structure: the case of the kelp Laminaria digitata in the English Channel. Marine Ecology Progress Series, 253, 1-121.

This article is protected by copyright. All rights reserved. 
Billot C, Rousvoal S, Estoup A, et al. (1998) Isolation and characterization of microsatellite markers in the nuclear genome of the brown alga Laminaria digitata (Phaeophyceae). Molecular Ecology, 7, 1778-1780.

Birkett DA, Maggs CA, Dring MJ, Boaden PJS, Seed R (1998) Infralittoral reef biotopes with kelp species. In: An Overview of Dynamic and Sensitivity Characteristics for Conservation Management of Marine SACs, p. 174.

Bjørnstad O (2009) ncf: spatial nonparametric covariance functions. R package version 1.1-3. http://cran.r-project.org/package=ncf

Bridle JR, Vines TH (2007) Limits to evolution at range margins: when and why does adaptation fail? Trends in Ecology \& Evolution, 22, 140-147.

Charlesworth B, Charlesworth D, Barton NH (2003) The effects of genetic and geographic structure on neutral variation. Annual Review of Ecology, Evolution, and Systematics, 34, 99-125.

Clarke KR, Gorley RN (2006) PRIMER ver. 6. User Manual/Tutorial. PRIMER-E: Plymouth, $U K$.

Coleman MA, Kelaher BP (2009) Connectivity among fragmented populations of a habitatforming alga, Phyllospora comosa (Phaeophyceae, Fucales) on an urbanised coast. Marine Ecology Progress Series, 381, 63-70.

Couceiro L, Robuchon M, Destombe C, Valero M (2013) Management and conservation of the kelp species Laminaria digitata: using genetic tools to explore the potential exporting role of the MPA "Parc naturel marin d'Iroise". Aquatic Living Resources, 26, 197-205.

This article is protected by copyright. All rights reserved. 
Diekmann OE, Serrão EA (2012) Range-edge genetic diversity: locally poor extant southern patches maintain a regionally diverse hotspot in the seagrass Zostera marina. Molecular Ecology, 21, 1647-1657.

Dorken ME, Eckert CG (2001) Severely reduced sexual reproduction in northern populations of a clonal plant, Decodonverticillatus (Lythraceae). Journal of Ecology, 89, 339-350.

Duminil J, Fineschi S, Hampe A, et al. (2007) Can population genetic structure be predicted from life-history traits? The American Naturalist, 169, 662-672.

Durrant $\mathrm{H}$, Burridge $\mathrm{CP}$, Kelaher BP, et al. (in press) Implications of macroalgal isolation by distance for networks of marine protected areas. Conservation Biology.

Eckert CG, Samis KE, Lougheed SC (2008) Genetic variation across species' geographical ranges: the central-marginal hypothesis and beyond. Molecular Ecology, 17, 11701188.

Engel CR, Destombe C, Valero M (2004) Mating system and gene flow in the red seaweed Gracilaria gracilis: effect of haploid-diploid life history and intertidal rocky shore landscape on finescale genetic structure. Heredity, 92, 289-298.

Excoffier L, Laval G, Schneider S (2005) ARLEQUIN (version 3.0): an integrated software package for population genetics data analysis. Evolutionary Bioinformatics Online, 1, 47-50.

Faugeron S, Martínez EA, Correa JA, et al. (2004) Reduced genetic diversity and increased population differentiation in peripheral and overharvested populations of Gigartina skottsbergii (Rhodophyta, Gigartinales) in Southern Chile. Journal of Phycology, 40, 454-462.

This article is protected by copyright. All rights reserved. 
Faugeron S, Valero M, Destombe C, Martínez EA, Correa JA (2001) Hierarchical spatial structure and discriminant analysis of genetic diversity in the red alga Mazzaella laminarioides (Gigartinales, Rhodophyta). Journal of Phycology, 37, 705-716.

Frankel OH, Soulé ME (1981) Conservation and evolution. Cambridge University Press.

Fraser C, Thiel M, Spencer H, Waters J (2010) Contemporary habitat discontinuity and historic glacial ice drive genetic divergence in Chilean kelp. BMC Evolutionary Biology, 10, 203-215.

Gallon RK, Robuchon M, Leroy B, et al. (in review for Journal of Biogeography) Observed and predicted distributional shifts of subtidal red seaweeds along a biogeographical transition zone in the context of global change.

Goudet J (1999) PCAGEN, a computer package which performs principal component analysis (PCA) on gene frequency data.

Goudet J (2001) FSTAT, a program to estimate and test gene diversities and fixation indices (version 2.9. 3).

Guo Q (2012) Incorporating latitudinal and central-marginal trends in assessing genetic variation across species ranges. Molecular Ecology, 21, 5396-5403.

Hampe A, Petit RJ (2005) Conserving biodiversity under climate change: the rear edge matters. Ecology Letters, 8, 461-467.

Hamrick J, Godt M (1996) Effects of life history traits on genetic diversity in plant species. Philosophical Transactions of the Royal Society of London. Series B: Biological Sciences, 351, 1291-1298.

Hedgecock D, Barber PH, Edmands S (2007) Genetic approaches to measuring connectivity. Oceanography, 20, 70-79.

This article is protected by copyright. All rights reserved. 
Helmuth BS, Hofmann GE (2001) Microhabitats, thermal heterogeneity, and patterns of physiological stress in the rocky intertidal zone. The Biological Bulletin, 201, 374384.

Hewitt GM (1996) Some genetic consequences of ice ages, and their role in divergence and speciation. Biological Journal of the Linnean Society, 58, 247-276.

Hop H, Wiencke C, Vögele B, Kovaltchouk NA (2012) Species composition, zonation, and biomass of marine benthic macroalgae in Kongsfjorden, Svalbard. Botanica Marina, $\mathbf{5 5}, 399-414$.

Hughes AR, Inouye BD, Johnson MTJ, Underwood N, Vellend M (2008) Ecological consequences of genetic diversity. Ecology Letters, 11, 609-623.

Ibrahim KM, Nichols RA, Hewitt GM (1996) Spatial patterns of genetic variation generated by different forms of dispersal. Heredity, 77, 282-291.

Johansson M, Banks M, Glunt K, Hassel-Finnegan H, Buonaccorsi V (2008) Influence of habitat discontinuity, geographical distance, and oceanography on fine-scale population genetic structure of copper rockfish (Sebastes caurinus). Molecular Ecology, 17, 3051-3061.

Kain JM (1971) Synopsis of biological data on Laminaria hyperborea (ed. FAO Fisheries synopsis), pp. 1-69.

Kelly RP, Palumbi SR (2010) Genetic structure among 50 species of the northeastern Pacific rocky intertidal community. PLoS ONE, 5, e8594.

Kerswell AP (2006) Global biodiversity patterns of benthic marine algae. Ecology, 87, 24792488.

Kimura M, Weiss GH (1964) The stepping stone model of population structure and the decrease of genetic correlation with distance. Genetics, 49, 561-576.

This article is protected by copyright. All rights reserved. 
Kinlan BP, Gaines SD, Lester SE (2005) Propagule dispersal and the scales of marine community process. Diversity and Distributions, 11, 139-148.

Krueger-Hadfield S, Roze D, Mauger S, Valero M (2013) Intergametophytic selfing and microgeographic genetic structure shape populations of the intertidal red seaweed Chondrus crispus. Molecular Ecology, 22, 3242-3260.

Leclerc J-C (2013) Biodiversité, structure et fonctionnement trophique des communautés associées à Laminaria hyperborea, en conditions naturelles et exploitées, en Bretagne. PhD Thesis, Université Pierre et Marie Curie, Paris.

Lobban CS, Harrison PJ (1994) Seaweed ecology and physiology. Cambridge University Press.

Lüning K (1990) Seaweeds: their environment, biogeography, and ecophysiology. John Wiley \& Sons, New-York.

Lüning, K, Muller DG (1978). Chemical interaction in sexual reproduction of several Laminariales (Phaeophyceae): release and attraction of spermatozoids. Zeit- schrift fur Pflanzenphysiologie, 89, 333-341.

Macaya EC, Boltaña S, Hinojosa IA, et al. (2005) Presence of sporophylls in floating kelp rafts of Macrocystis spp. (Phaeophyceae) along the Chilean Pacific coast. Journal of Phycology, 41, 913-922.

Maggs CA, Castilho R, Foltz D, et al. (2008) Evaluating signatures of glacial refugia for North Atlantic benthic marine taxa. Ecology, 89, S108-S122.

Marko P (2004) 'What's larvae got to do with it?'Disparate patterns of post-glacial population structure in two benthic marine gastropods with identical dispersal potential. Molecular Ecology, 13, 597-611.

This article is protected by copyright. All rights reserved. 
Mauger S, Couceiro L, Valero M (2012) A simple and cost-effective method to synthesize an internal size standard amenable to use with a 5-dye system. Prime Research on Biotechnology, 2, 40-46.

McCauley DE (1991) Genetic consequences of local population extinction and recolonization. Trends in Ecology and Evolution, 6, 5-8.

McDevit DC, Saunders GW (2010) A DNA barcode examination of the Laminariaceae (Phaeophyceae) in Canada reveals novel biogeographical and evolutionary insights. Phycologia, 49, 235-248.

Nei M (1987) Molecular Evolutionary Genetics. Columbia University Press, New-York.

Nybom H (2004) Comparison of different nuclear DNA markers for estimating intraspecific genetic diversity in plants. Molecular Ecology, 13, 1143-1155.

Oppliger LV (2010) Reproduction des grandes algues brunes des côtes Chiliennes et Bretonnes en marge de leur aire de distribution. $\mathrm{PhD}$ Thesis, Université Pierre et Marie Curie, Paris.

Oppliger LV, Von Dassow P, Bouchemousse S, et al. (in review for PLoS ONE ) Alteration of sexual reproduction and genetic diversity in the kelp species Laminaria digitata at the southern limit of its range.

Peakall ROD, Smouse PE (20012) GENALEX 6.5: genetic analysis in Excel. Population genetic software for teaching and research - an update. Bioinformatics, 28, 25372539.

Provan J, Wattier RA, Maggs CA (2005) Phylogeographic analysis of the red seaweed Palmaria palmata reveals a Pleistocene marine glacial refugium in the English Channel. Molecular Ecology, 14, 793-803.

This article is protected by copyright. All rights reserved. 
Provan J, Maggs CA (2012) Unique genetic variation at a species' rear edge is under threat from global climate change. Proceedings of the Royal Society B: Biological Sciences, 279, 39-47.

R Development Core Team (2005) R: a language and environment for statistical computing. R Foundation for Statistical Computing, Vienna, Austria.

Raimondi PT, Reed DC, Gaylord B, Washburn L (2004) Effects of self-fertilization in the giant kelp, Macrocystis pyrifera. Ecology, 85, 3267-3276.

Reed DC (1990) The effects of variable settlement and early competition on patterns of kelp recruitment. Ecology, 71, 776-787.

Riginos C, Nachman M (2001) Population subdivision in marine environments: the contributions of biogeography, geographical distance and discontinuous habitat to genetic differentiation in a blennioid fish, Axoclinus nigricaudus. Molecular Ecology, 10, 1439-1453.Rousset F (1997) Genetic differentiation and estimation of gene flow from F-statistics under isolation by distance. Genetics, 145, 1219-1228.

Santelices B (1990) Patterns of reproduction, dispersal and recruitment in seaweeds. Oceanography and Marine Biology: an Annual Review, 28, 177-276.

Smale DA, Burrows MT, Moore P, O'Connor N, Hawkins SJ (2013) Threats and knowledge gaps for ecosystem services provided by kelp forests: a northeast Atlantic perspective. Ecology and Evolution, 3, 4016-4038.

Steneck RS, Graham MH, Bourque BJ, et al. (2002) Kelp forest ecosystems: biodiversity, stability, resilience and future. Environmental Conservation, 29, 436-459.

Valero M, Destombe C, Mauger S, et al. (2011) Using genetic tools for sustainable management of kelps: a literature review and the example of Laminaria digitata. Cahiers de Biologie Marine, 52, 467-483.

This article is protected by copyright. All rights reserved. 
van Etten J (2012) gdistance: distances and routes on geographical grids. R package version 1.1-4. http://cran.r-project.org/package=gdistance

van Oosterhout C, Hutchinson WF, Wills DP, Shipley P (2004) MICRO-CHECKER: software for identifying and correcting genotyping errors in microsatellite data. Molecular Ecology Notes, 4, 535-538.

Vucetich JA, Waite TA (2003) Spatial patterns of demography and genetic processes across the species' range: null hypotheses for landscape conservation genetics. Conservation Genetics, 4, 639-645.

Walser B, Haag CR (2012). Strong intraspecific variation in genetic diversity and genetic differentiation in Daphnia magna: the effects of population turnover and population size. Molecular Ecology, 21, 851-861.

Watts RJ, Johnson MS (2004) Estuaries, lagoons and enclosed embayments: habitats that enhance population subdivision of inshore fishes. Marine and Freshwater Research, 55, 641-651.

Weir BS, Cockerham CC (1984) Estimating F-statistics for the analysis of population structure. Evolution, 38, 1358-1370.

White C, Selkoe KA, Watson J, et al. (2010) Ocean currents help explain population genetic structure. Proceedings of the Royal Society B: Biological Sciences, 277, 1685-1694.

Wilkins JF, Wakeley J (2002) The coalescent in a continuous, finite, linear population. Genetics, 161, 873-888.

Wright S (1943) Isolation by distance. Genetics, 28, 114-138.

This article is protected by copyright. All rights reserved. 


\section{Data accessibility}

- Microsatellites sequences: Genbank accessions AJ003161 - AJ003162 - Y17350 Y17351 - Y17346 - Y17348 - KF767485 - KF767490 - KF767492 - KF767494 KF767495 - KF767497 - KF767498

- Microsatellites genotypes uploaded as online supplemental material and in Dryad doi:10.5061/dryad.pv28c

\section{Author contributions}

M.R., L.L. and M.V. conceived and designed the experiments. M.R., L.L. and M.V. collected samples. M.R. genotyped $L d$ samples and S.M. L. hyperborea samples. M.R., M.V. and S.M. participated in data analysis and synthesis. M.R. wrote the manuscript with contributions from all authors.

\section{Figure Legends}

Fig. 1 Diagram showing the characteristics of Laminaria digitata (top) and Laminaria hyperborea (bottom).

Fig. 2 (a) Diagram of the hierarchical sampling design (a black circle is a site, a dotted circle is a locality and a dotted square is a region) and (b) map of kelp collection sites in Brittany, France. Sites are: Guimereux (1), La Bigne (2), Nerput (3), Le Moulin (4), Les Amas du Cap (5), Primel (6), Duons Est (7), Duons Ouest (8), Santec 2 (9), Santec 1 (10), Les Amiettes (11), Les Linious (12), Men Vriant (13), Klosenn Malaga (14), Les Rospects (15), St Mathieu

This article is protected by copyright. All rights reserved. 
(16), Pointe du Grand Gouin (17), Ile Téviec (18), Houat 2 (19), Houat 1 (20) and Hoedic (21). For site coordinates, see Table1.

Fig. 3 Comparison of genetic diversity estimates between Laminaria digitata (Ld) and Laminaria hyperborea (Lh) across space. (a) Allelic richness (AR) by region, (b) AR by site, (c) Expected heterozygosity $\left(H_{\mathrm{e}}\right)$ by region and (d) $H_{\mathrm{e}}$ by site. Dots are mean values, bars are standard errors and dashed lines link dots to highlight putative interactions between species and space. Means and errors were calculated over loci for (b) and (d), over loci and sites for (a) and (c). For site names, see Fig.1 and Table1. Sites 1, 3 and 16 were not included because they had fewer than 19 individuals for at least one species; site 18 was not considered because L. digitata was not sampled there.

Fig. 4 Principal components analysis (PCA) based on allele frequencies of (a) Laminaria digitata populations (cumulative inertia for the first two axes $=71.2 \%$ ) and (b) Laminaria hyperborea populations (cumulative inertia for the first two axes $=86.2 \%$ ). Inertia percentages are indicated along each axis. For site names, see Fig. 2 and Table1.

Fig. 5 Isolation by distance of (a) all pairs of Laminaria digitata populations, (b) all pairs of Laminaria hyperborea populations, (c) pairs of populations within regions for L. digitata and (d) pairs of populations within regions for L. hyperborea. Estimates of pairwise genetic differentiation $\left[F_{\mathrm{ST}} /\left(1-F_{\mathrm{ST}}\right)\right]$ is plotted against pairwise site distance in kilometres. Mantel non-parametric tests based on 1000 permutations between pairwise genetic differentiation and pairwise site distance are given.

This article is protected by copyright. All rights reserved. 


\section{Supporting information}

Additional supporting information may be found in the online version of this article

Table S1 Microsatellite genotypes of Laminaria digitata individuals in GeneAlex format

Table S2 Microsatellite genotypes of Laminaria hyperborea individuals in GeneAlex format

Table S3 Results of the pairwise tests testing the differences in allelic richness between species within each region and among regions within each species

Table S4 Genetic diversity estimates by locus for Laminaria digitata

Table S5 Genetic diversity estimates by locus for Laminaria hyperborea

Table S6 Laminaria digitata pairwise $F_{\mathrm{ST}}$ and their associated probabilities as calculated in FSTAT

Table S7 Laminaria hyperborea pairwise $F_{\mathrm{ST}}$ and their probabilities as calculated in FSTAT

This article is protected by copyright. All rights reserved. 
Table 1 Geographic locations, size, multilocus genetic and genotypic diversity estimates for samples (a) of Laminaria digitata on 11 microsatellite loci and (b) of Laminaria hyperborea on 9 microsatellite loci; to see which sites belong to the same locality, see Fig. 2

(a) L. digitata

\begin{tabular}{|c|c|c|c|c|c|c|c|c|c|c|}
\hline $\begin{array}{l}\text { Site } \\
\text { (number) }\end{array}$ & GPS coo & dinates & $\begin{array}{c}\text { Harvesting } \\
\#\end{array}$ & $\mathbf{N}$ & $N_{\mathrm{a}}$ & $\begin{array}{c}\mathbf{A R} \\
\S\end{array}$ & $H_{\mathrm{e}}$ & $\boldsymbol{P}_{\mathrm{a}}$ & $R$ & $F_{\text {IS }}$ \\
\hline $\begin{array}{l}\text { Guimereux } \\
\text { (1) }\end{array}$ & 48.69658 & $\begin{array}{c}- \\
1.96063\end{array}$ & No & 7 & $\begin{array}{c}2.5 \\
\pm \\
0.3\end{array}$ & $x$ & $\begin{array}{c}0.412 \\
\pm \\
0.069\end{array}$ & 0 & 1.00 & 0.150 \\
\hline La Bigne (2) & 48.69452 & $\begin{array}{c}- \\
1.98453\end{array}$ & No & 46 & $\begin{array}{c}4.1 \\
\pm \\
0.6\end{array}$ & $\begin{array}{c}3.3 \\
\pm \\
0.4\end{array}$ & $\begin{array}{c}0.390 \\
\pm \\
0.065\end{array}$ & 6 & 0.96 & $\begin{array}{c}- \\
0.054\end{array}$ \\
\hline Nerput (3) & 48.65248 & $\begin{array}{c}- \\
2.14033\end{array}$ & No & 12 & $\begin{array}{c}2.7 \\
\pm \\
0.4\end{array}$ & $x$ & $\begin{array}{c}0.356 \\
\pm \\
0.073\end{array}$ & 0 & 1.00 & $\begin{array}{c}- \\
0.065\end{array}$ \\
\hline $\begin{array}{l}\text { Le Moulin } \\
\text { (4) }\end{array}$ & 48.65113 & $\begin{array}{c}- \\
2.11750\end{array}$ & No & 40 & $\begin{array}{c}3.3 \\
\pm \\
0.6\end{array}$ & $\begin{array}{c}2.9 \\
\pm \\
0.5\end{array}$ & $\begin{array}{c}0.415 \\
\pm \\
0.069\end{array}$ & 0 & 0.97 & $\begin{array}{c}- \\
0.054\end{array}$ \\
\hline $\begin{array}{l}\text { Les Amas du } \\
\text { Cap (5) }\end{array}$ & 48.68785 & $\begin{array}{c}- \\
2.32502\end{array}$ & No & 59 & $\begin{array}{c}4.0 \\
\pm \\
0.8\end{array}$ & $\begin{array}{c}3.2 \\
\pm \\
0.6\end{array}$ & $\begin{array}{c}0.349 \\
\pm \\
0.082\end{array}$ & 1 & 1.00 & 0.058 \\
\hline $\begin{array}{l}\text { St Malo Bay } \\
\text { (SMB) }\end{array}$ & & & & 164 & $\begin{array}{r}5.7 \\
\pm\end{array}$ & $\begin{array}{l}5.4 \\
\pm\end{array}$ & $\begin{array}{c}0.394 \\
\pm\end{array}$ & 8 & & \\
\hline & & & & & 0.8 & 0.8 & 0.069 & & & \\
\hline Primel (6) & 48.72933 & $\begin{array}{c}- \\
3.78566\end{array}$ & No & 55 & $\begin{array}{c}5.1 \\
\pm \\
0.8\end{array}$ & $\begin{array}{c}4.2 \\
\pm \\
0.6\end{array}$ & $\begin{array}{c}0.496 \\
\pm \\
0.077\end{array}$ & 1 & 1.00 & 0.145 \\
\hline
\end{tabular}

This article is protected by copyright. All rights reserved. 


\begin{tabular}{|c|c|c|c|c|c|c|c|c|c|c|}
\hline & & & & & & & & & & $*$ \\
\hline Duons Est (7) & 48.72490 & $\begin{array}{c}- \\
3.91978\end{array}$ & Yes (light) & 48 & $\begin{array}{c}6.2 \\
\pm \\
1.0\end{array}$ & $\begin{array}{c}5.1 \\
\pm \\
0.8\end{array}$ & $\begin{array}{c}0.527 \\
\pm \\
0.078\end{array}$ & 3 & 1.00 & 0.057 \\
\hline $\begin{array}{l}\text { Duons Ouest } \\
\text { (8) }\end{array}$ & 48.72765 & $\begin{array}{c}- \\
3.92643\end{array}$ & Yes & 39 & $\begin{array}{c}6.1 \\
\pm \\
1.1\end{array}$ & $\begin{array}{c}5.1 \\
\pm \\
0.9\end{array}$ & $\begin{array}{c}0.504 \\
\pm \\
0.089\end{array}$ & 2 & 1.00 & 0.019 \\
\hline Santec 2 (9) & 48.72603 & $\begin{array}{c}- \\
4.02358\end{array}$ & Yes & 41 & $\begin{array}{c}6.5 \\
\pm \\
1.3\end{array}$ & $\begin{array}{c}5.4 \\
\pm \\
1.1\end{array}$ & $\begin{array}{c}0.542 \\
\pm \\
0.075\end{array}$ & 3 & 0.90 & $\begin{array}{c}- \\
0.021\end{array}$ \\
\hline Santec 1 (10) & 48.72207 & $\begin{array}{c}- \\
4.04282\end{array}$ & Yes & 27 & $\begin{array}{c}6.3 \\
\pm \\
1.1\end{array}$ & $\begin{array}{c}5.5 \\
\pm \\
0.9\end{array}$ & $\begin{array}{c}0.555 \\
\pm \\
0.068\end{array}$ & 3 & 1.00 & 0.078 \\
\hline $\begin{array}{l}\text { Les Amiettes } \\
\text { (11) }\end{array}$ & 48.70239 & $\begin{array}{c}- \\
4.13978\end{array}$ & No & 35 & $\begin{array}{c}6.1 \\
\pm \\
1.0\end{array}$ & $\begin{array}{c}5.3 \\
\pm \\
0.9\end{array}$ & $\begin{array}{c}0.559 \\
\pm \\
0.067\end{array}$ & 0 & 1.00 & 0.061 \\
\hline Morlaix Bay & & & & 245 & 8.7 & 7.9 & 0.534 & 13 & & \\
\hline (MoB) & & & & & $\begin{array}{c} \pm \\
1.4\end{array}$ & $\begin{array}{c} \pm \\
1.3\end{array}$ & $\begin{array}{c} \pm \\
0.074\end{array}$ & & & \\
\hline $\begin{array}{l}\text { Les Linious } \\
\text { (12) }\end{array}$ & 48.49265 & $\begin{array}{c}- \\
4.80418\end{array}$ & No & 47 & $\begin{array}{c}6.0 \\
\pm \\
1.0\end{array}$ & $\begin{array}{c}5.0 \\
\pm \\
0.7\end{array}$ & $\begin{array}{c}0.565 \\
\pm \\
0.066\end{array}$ & 1 & 1.00 & 0.034 \\
\hline $\begin{array}{l}\text { Men Vriant } \\
\text { (13) }\end{array}$ & 48.38640 & $\begin{array}{c}- \\
4.93168\end{array}$ & Yes & 42 & $\begin{array}{c}7.3 \\
\pm \\
1.2\end{array}$ & $\begin{array}{c}5.8 \\
\pm \\
0.9\end{array}$ & $\begin{array}{c}0.619 \\
\pm \\
0.057\end{array}$ & 2 & 1.00 & 0.043 \\
\hline $\begin{array}{l}\text { Klosenn } \\
\text { Malaga (14) }\end{array}$ & 48.38153 & $\begin{array}{c}- \\
4.91928\end{array}$ & Yes & 42 & $\begin{array}{c}6.8 \\
\pm \\
0.9\end{array}$ & $\begin{array}{c}5.9 \\
\pm \\
0.8\end{array}$ & $\begin{array}{c}0.601 \\
\pm \\
0.057\end{array}$ & 1 & 1.00 & 0.079 \\
\hline Les Rospects & 48.32560 & $\begin{array}{c}- \\
4.76412\end{array}$ & No & 34 & $\begin{array}{c}7.1 \\
\pm \\
0.9\end{array}$ & $\begin{array}{c}6.1 \\
\pm \\
0.8\end{array}$ & $\begin{array}{c}0.618 \\
\pm \\
0.058\end{array}$ & 2 & 1.00 & 0.087 \\
\hline
\end{tabular}

This article is protected by copyright. All rights reserved. 


\begin{tabular}{|c|c|c|c|c|c|c|c|c|c|c|}
\hline (15) & & & & & & & & & & \\
\hline $\begin{array}{l}\text { St Mathieu } \\
\text { (16) }\end{array}$ & 48.32770 & $\begin{array}{c}- \\
4.75218\end{array}$ & No & 19 & $\begin{array}{c}5.3 \\
\pm \\
0.8\end{array}$ & $x$ & $\begin{array}{c}0.593 \\
\pm \\
0.063\end{array}$ & 1 & 1.00 & 0.135 \\
\hline $\begin{array}{l}\text { Pointe du } \\
\text { Grand Gouin }\end{array}$ & 48.28812 & $\begin{array}{c}- \\
4.60160\end{array}$ & No & 37 & $\begin{array}{c}6.2 \\
\pm \\
1.1\end{array}$ & $\begin{array}{c}5.5 \\
\pm \\
1.0\end{array}$ & $\begin{array}{l}0.624 \\
\pm \\
0.070\end{array}$ & 1 & 1.00 & 0.121 \\
\hline (17) & & & & & & & & & & \\
\hline Iroise Sea & & & & 221 & 9.1 & 8.5 & 0.612 & 13 & & \\
\hline (IrS) & & & & & $\begin{array}{c} \pm \\
1.1\end{array}$ & $\begin{array}{c} \pm \\
1.1\end{array}$ & $\begin{array}{c} \pm \\
0.061\end{array}$ & & & \\
\hline Houat 2 (19) & 47.39488 & $\begin{array}{c}- \\
2.96202\end{array}$ & No & 33 & $\begin{array}{c}3.8 \\
\pm \\
0.4\end{array}$ & $\begin{array}{c}3.5 \\
\pm \\
0.3\end{array}$ & $\begin{array}{c}0.521 \\
\pm \\
0.052\end{array}$ & 0 & 1.00 & 0.062 \\
\hline Houat 1 (20) & 47.39452 & $\begin{array}{c}- \\
2.95820\end{array}$ & No & 70 & $\begin{array}{c}3.7 \\
\pm \\
0.4\end{array}$ & $\begin{array}{c}3.2 \\
\pm \\
0.3\end{array}$ & $\begin{array}{c}0.489 \\
\pm \\
0.059\end{array}$ & 0 & 0.94 & 0.048 \\
\hline Hoedic (21) & 47.33872 & $\begin{array}{c}- \\
2.89227\end{array}$ & No & 31 & $\begin{array}{c}4.1 \\
\pm \\
0.4\end{array}$ & $\begin{array}{c}3.8 \\
\pm \\
0.4\end{array}$ & $\begin{array}{l}0.551 \\
\pm \\
0.057\end{array}$ & 0 & 1.00 & $\begin{array}{c}- \\
0.012\end{array}$ \\
\hline Southern & & & & 134 & 4.8 & 4.8 & 0.521 & $\mathbf{0}$ & & \\
\hline Brittany & & & & & \pm & \pm & \pm & & & \\
\hline (SBr) & & & & & 0.5 & 0.5 & 0.054 & & & \\
\hline
\end{tabular}

\section{(b) L. hyperborea}

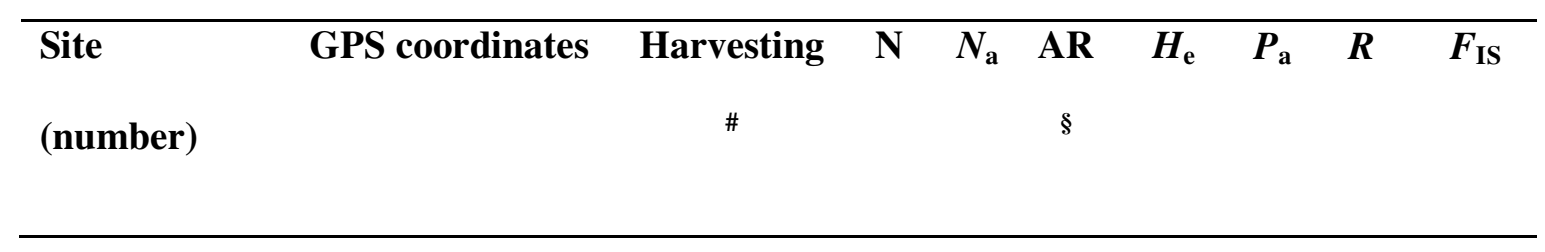

This article is protected by copyright. All rights reserved. 


\begin{tabular}{|c|c|c|c|c|c|c|c|c|c|c|}
\hline $\begin{array}{l}\text { Guimereux } \\
\text { (1) }\end{array}$ & 48.69658 & $\begin{array}{c}- \\
1.96063\end{array}$ & No & 42 & $\begin{array}{c}3.4 \\
\pm \\
0.3\end{array}$ & $\begin{array}{c}3.0 \\
\pm \\
0.3\end{array}$ & $\begin{array}{c}0.446 \\
\pm \\
0.068\end{array}$ & 2 & 0.95 & 0.116 \\
\hline La Bigne (2) & 48.69452 & $\begin{array}{c}- \\
1.98453\end{array}$ & No & 56 & $\begin{array}{c}4.0 \\
\pm \\
0.6\end{array}$ & $\begin{array}{c}3.3 \\
\pm \\
0.4\end{array}$ & $\begin{array}{c}0.490 \\
\pm \\
0.071\end{array}$ & 0 & 0.98 & 0.115 \\
\hline Nerput (3) & 48.65248 & $\begin{array}{c}- \\
2.14033\end{array}$ & No & 31 & $\begin{array}{c}3.1 \\
\pm \\
0.5\end{array}$ & $\begin{array}{c}2.9 \\
\pm \\
0.4\end{array}$ & $\begin{array}{c}0.429 \\
\pm \\
0.068\end{array}$ & 0 & 1.00 & 0.173 \\
\hline $\begin{array}{l}\text { Le Moulin } \\
\text { (4) }\end{array}$ & 48.65113 & $\begin{array}{c}- \\
2.11750\end{array}$ & No & 56 & $\begin{array}{c}3.3 \\
\pm \\
0.5\end{array}$ & $\begin{array}{c}2.9 \\
\pm \\
0.4\end{array}$ & $\begin{array}{c}0.446 \\
\pm \\
0.071\end{array}$ & 0 & 1.00 & 0.076 \\
\hline $\begin{array}{l}\text { Les Amas du } \\
\text { Cap (5) }\end{array}$ & 48.68785 & $\begin{array}{c}- \\
2.33037\end{array}$ & No & 63 & $\begin{array}{c}4.1 \\
\pm \\
0.5\end{array}$ & $\begin{array}{c}3.3 \\
\pm \\
0.4\end{array}$ & $\begin{array}{c}0.456 \\
\pm \\
0.077\end{array}$ & 0 & 1.00 & $\begin{array}{c}- \\
0.009\end{array}$ \\
\hline $\begin{array}{l}\text { St Malo Bay } \\
\text { (SMB) }\end{array}$ & & & & 248 & $\begin{array}{r}5.4 \\
\pm \\
0.6\end{array}$ & $\begin{array}{r}4.8 \\
\pm \\
0.5\end{array}$ & $\begin{array}{c}0.461 \\
\pm \\
0.071\end{array}$ & 2 & & \\
\hline Primel (6) & 48.72933 & $\begin{array}{c}- \\
3.78566\end{array}$ & No & 38 & $\begin{array}{c}5.6 \\
\pm \\
0.6\end{array}$ & $\begin{array}{c}4.8 \\
\pm \\
0.5\end{array}$ & $\begin{array}{c}0.566 \\
\pm \\
0.089\end{array}$ & 0 & 1.00 & 0.066 \\
\hline Duons Est (7) & 48.72595 & $\begin{array}{c}- \\
3.91408\end{array}$ & No & 50 & $\begin{array}{c}5.8 \\
\pm \\
0.8\end{array}$ & $\begin{array}{c}4.9 \\
\pm \\
0.6\end{array}$ & $\begin{array}{c}0.591 \\
\pm \\
0.090\end{array}$ & 4 & 1.00 & $\begin{array}{c}- \\
0.016\end{array}$ \\
\hline $\begin{array}{l}\text { Duons Ouest } \\
\text { (8) }\end{array}$ & 48.72765 & $\begin{array}{c}- \\
3.92643\end{array}$ & No & 81 & $\begin{array}{c}5.8 \\
\pm \\
0.6\end{array}$ & $\begin{array}{c}4.7 \\
\pm \\
0.6\end{array}$ & $\begin{array}{c}0.584 \\
\pm \\
0.088\end{array}$ & 0 & 1.00 & 0.027 \\
\hline Santec 2 (9) & 48.72603 & $\begin{array}{c}- \\
4.02358\end{array}$ & Yes & 39 & $\begin{array}{c}5.4 \\
\pm \\
0.7\end{array}$ & $\begin{array}{c}4.9 \\
\pm \\
0.7\end{array}$ & $\begin{array}{c}0.611 \\
\pm \\
0.093\end{array}$ & 1 & 1.00 & 0.061 \\
\hline
\end{tabular}

This article is protected by copyright. All rights reserved. 


\begin{tabular}{|c|c|c|c|c|c|c|c|c|c|c|}
\hline Santec 1 (10) & 48.72207 & $\begin{array}{c}- \\
4.04282\end{array}$ & Yes & 45 & $\begin{array}{c}5.0 \\
\pm \\
0.7\end{array}$ & $\begin{array}{c}4.5 \\
\pm \\
0.6\end{array}$ & $\begin{array}{c}0.582 \\
\pm \\
0.097\end{array}$ & 0 & 1.00 & 0.025 \\
\hline $\begin{array}{l}\text { Les Amiettes } \\
\text { (11) }\end{array}$ & 48.70239 & $\begin{array}{c}- \\
4.13978\end{array}$ & No & 44 & $\begin{array}{c}5.4 \\
\pm \\
0.6\end{array}$ & $\begin{array}{c}4.9 \\
\pm \\
0.5\end{array}$ & $\begin{array}{c}0.613 \\
\pm \\
0.084\end{array}$ & 2 & 1.00 & 0.068 \\
\hline $\begin{array}{l}\text { Morlaix Bay } \\
(\text { MoB) }\end{array}$ & & & & 297 & $\begin{array}{l}7.4 \\
\pm \\
0.9\end{array}$ & $\begin{array}{l}6.4 \\
\pm \\
0.7\end{array}$ & $\begin{array}{c}0.591 \\
\pm \\
0.089\end{array}$ & 8 & & \\
\hline $\begin{array}{l}\text { Les Linious } \\
\text { (12) }\end{array}$ & 48.49265 & $\begin{array}{c}- \\
4.80418\end{array}$ & No & 50 & $\begin{array}{c}5.2 \\
\pm \\
0.6\end{array}$ & $\begin{array}{c}4.8 \\
\pm \\
0.5\end{array}$ & $\begin{array}{c}0.597 \\
\pm \\
0.086\end{array}$ & 1 & 1.00 & 0.051 \\
\hline $\begin{array}{l}\text { Men Vriant } \\
\text { (13) }\end{array}$ & 48.38640 & $\begin{array}{c}- \\
4.93168\end{array}$ & No & 34 & $\begin{array}{c}5.0 \\
\pm \\
0.6\end{array}$ & $\begin{array}{c}4.6 \\
\pm \\
0.6\end{array}$ & $\begin{array}{c}0.590 \\
\pm \\
0.084\end{array}$ & 1 & 0.97 & 0.042 \\
\hline $\begin{array}{l}\text { Klosenn } \\
\text { Malaga (14) }\end{array}$ & 48.38153 & $\begin{array}{c}- \\
4.91928\end{array}$ & No & 46 & $\begin{array}{c}5.3 \\
\pm \\
0.6\end{array}$ & $\begin{array}{c}4.8 \\
\pm \\
0.5\end{array}$ & $\begin{array}{c}0.622 \\
\pm \\
0.081\end{array}$ & 0 & 0.98 & 0.017 \\
\hline $\begin{array}{l}\text { Les Rospects } \\
\text { (15) }\end{array}$ & 48.32560 & $\begin{array}{c}- \\
4.76412\end{array}$ & No & 40 & $\begin{array}{c}5.8 \\
\pm \\
0.7\end{array}$ & $\begin{array}{c}5.0 \\
\pm \\
0.6\end{array}$ & $\begin{array}{c}0.588 \\
\pm \\
0.090\end{array}$ & 2 & 1.00 & 0.023 \\
\hline $\begin{array}{l}\text { St Mathieu } \\
\text { (16) }\end{array}$ & 48.32770 & $\begin{array}{c}- \\
4.75218\end{array}$ & No & 59 & $\begin{array}{c}6.4 \\
\pm \\
0.8\end{array}$ & $\begin{array}{c}5.2 \\
\pm \\
0.6\end{array}$ & $\begin{array}{c}0.590 \\
\pm \\
0.087\end{array}$ & 8 & 1.00 & 0.071 \\
\hline $\begin{array}{l}\text { Pointe du } \\
\text { Grand Gouin } \\
\text { (17) }\end{array}$ & 48.28812 & $\begin{array}{c}- \\
4.60160\end{array}$ & No & 42 & $\begin{array}{c}4.8 \\
\pm \\
0.5\end{array}$ & $\begin{array}{c}4.5 \\
\pm \\
0.5\end{array}$ & $\begin{array}{c}0.593 \\
\pm \\
0.075\end{array}$ & 0 & 1.00 & $\begin{array}{c}- \\
0.027\end{array}$ \\
\hline
\end{tabular}

This article is protected by copyright. All rights reserved. 


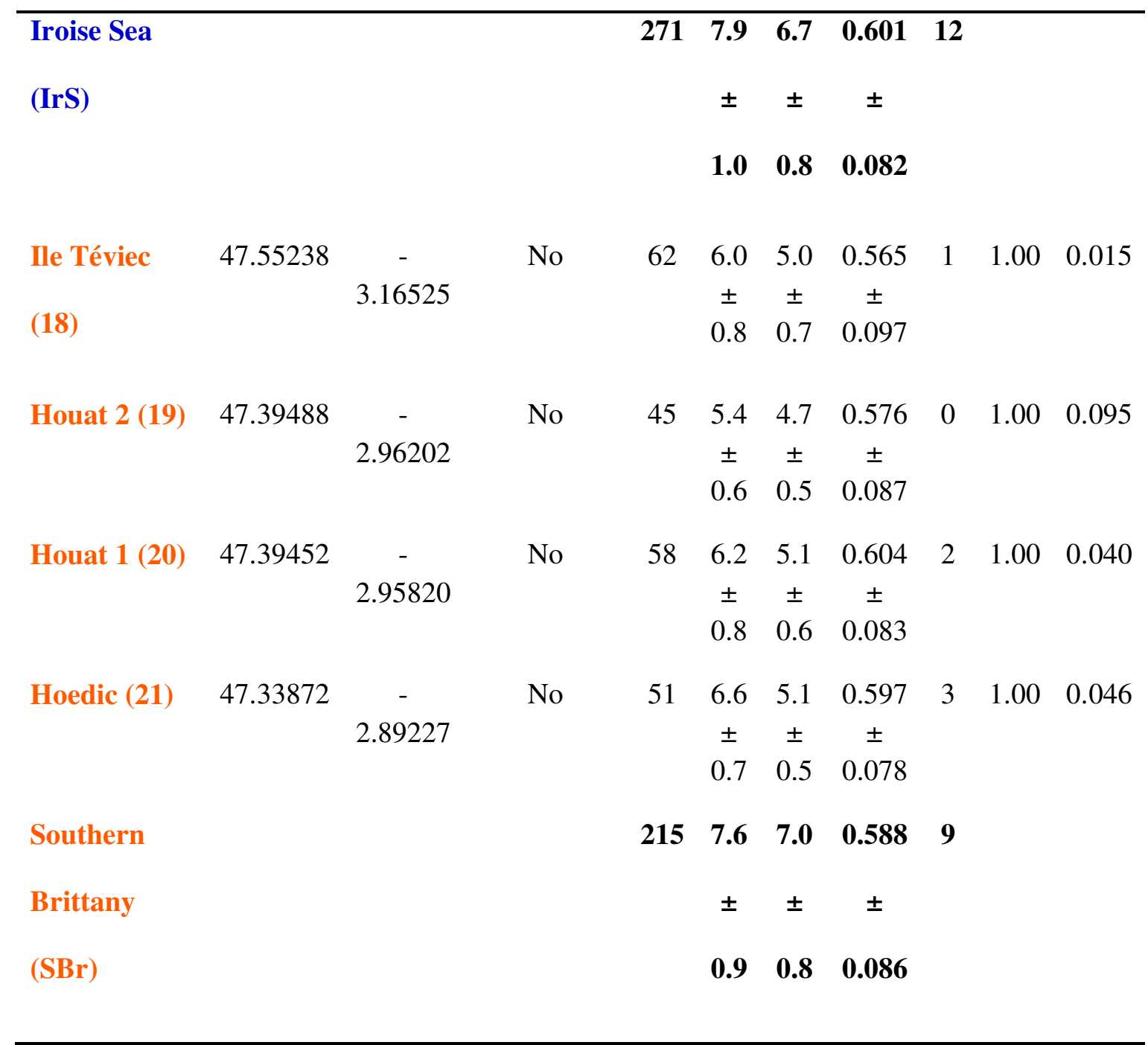

Sampling was carried out at the same sites for both species except Ile Téviec where $L$.

digitata was not sampled and Duons Est and Les Amas du Cap where species' sites were separated by a few hundred meters. $\mathrm{N}$ is the number of individuals per sample; $N_{\mathrm{a}}$, number of alleles; AR, rarefied allelic richness; $H_{\mathrm{e}}$, expected heterozygosity as defined by Nei (1987); $P_{\mathrm{a}}$, the number of private alleles; $R$, genotypic diversity $(G-1 / N-1$, where $G$ is the number of distinct genotypes Dorken \& Eckert 2001); $F_{\text {IS }}$, inbreeding coefficient as defined by Weir \& Cockerham (1984) calculated overall loci. For $N_{\mathrm{a}}, \mathrm{AR}$ and $H_{\mathrm{e}}$, values are mean and standard errors over loci. Significant values of $F_{\text {IS }}(P<0.05)$ are indicated with an asterisk $(*)$. Regional (pooled site samples) sample size and genetic diversity estimates are shown in bold.

This article is protected by copyright. All rights reserved. 
${ }^{\S}$ For both species, AR values for each site were calculated with a rarefaction size of 19 diploid individuals and AR values for each region were calculated with a rarefaction size of 132 diploid individuals. " pers. comm., M. Laurans.

Table 2 Results of the PERMANOVA (permutational analysis of variance) testing the effects of the factors (a) 'species' and 'region' on allelic richness (AR), (b) 'species' and 'site' on the $\mathrm{AR},(\mathrm{c})$ 'species' and 'region' on the expected heterozygosity $\left(H_{\mathrm{e}}\right)$ and $(\mathrm{d})$ 'species' and 'site' on the $H_{\mathrm{e}}$; df, degrees of freedom; SS, sum of squares; Pseudo-F, the Pseudo-F statistic; and $P($ perm $)$, the probablity calculated by permutations.

(a) Effects of the factors 'species' and 'region' on AR

\begin{tabular}{lcccc}
\hline Source of variation & df & SS & Pseudo-F & $P($ perm $)$ \\
\hline Species & 1 & 1870 & 4.8 & 0.021 \\
Region & 3 & 16024 & 13.6 & $<0.001$ \\
Species*Region & 3 & 3609 & 3.1 & 0.017 \\
Residuals & 264 & $1.032 \times 10^{5}$ & & \\
Total & 271 & $1.239 \times 10^{5}$ & & \\
\hline
\end{tabular}

(b) Effects of the factors 'species' and 'site' on AR

\begin{tabular}{llccc}
\hline Source of variation & df & SS & Pseudo-F & $\boldsymbol{P}($ perm) \\
& & & & \\
\hline Species & 1 & 1025 & 2.4 & 0.107 \\
& & & & \\
\hline
\end{tabular}

This article is protected by copyright. All rights reserved. 


\begin{tabular}{lcccc}
\hline Site & 16 & 17723 & 2.6 & $<0.001$ \\
Species*Site & 16 & 4793 & 0.7 & 0.820 \\
Residuals & 238 & $1.032 \times 10^{5}$ & & \\
Total & 271 & $1.239 \times 10^{5}$ & & \\
& & & & \\
\hline
\end{tabular}

(c) Effects of the factors 'species' and 'region' on $H_{\mathrm{e}}$

\begin{tabular}{lcccc}
\hline Source of variation & df & SS & Pseudo-F & $P($ perm) \\
\hline Species & 1 & 451 & 6.4 & 0.011 \\
Region & 3 & 1116 & 5.3 & 0.002 \\
Species*Region & 3 & 97 & 0.5 & 0.713 \\
Residuals & 264 & 18517 & & \\
Total & 271 & 20181 & & \\
\end{tabular}

(d) Effects of the factors 'species' and 'site' on $H_{\mathrm{e}}$

\begin{tabular}{lcccc}
\hline Source of variation & df & SS & Pseudo-F & P(perm) \\
\hline Species & 1 & 451 & 5.8 & 0.016 \\
Site & 16 & 1172 & 0.9 & 0.518 \\
Species*Site & 16 & 181 & 0.1 & 1 \\
Residuals & 238 & 18377 & & \\
& & & & \\
\hline
\end{tabular}

This article is protected by copyright. All rights reserved. 
Table 3 Results of the analysis of molecular variance (AMOVA) averaged over loci for localities grouped by region for (a) Laminaria digitata and (b) Laminaria hyperborea

(a) L. digitata

\begin{tabular}{|c|c|c|c|c|c|}
\hline Source of variation & $\begin{array}{l}\text { Sum of } \\
\text { squares }\end{array}$ & $\begin{array}{c}\text { Variance } \\
\text { components }\end{array}$ & $\begin{array}{c}\% \\
\text { variation }\end{array}$ & $F$-statistic & $P$ \\
\hline Among regions & 378.8 & 0.303 & 9.4 & $F_{\mathrm{CT}}=0.094$ & $<0.001$ \\
\hline $\begin{array}{l}\text { Among localities within } \\
\text { regions }\end{array}$ & 99.2 & 0.075 & 2.3 & $F_{\mathrm{SC}}=0.026$ & $<0.001$ \\
\hline Within localities & 4278.4 & 2.836 & 88.3 & & \\
\hline Total & 4756.5 & 3.213 & & & \\
\hline
\end{tabular}

Global $F_{\mathrm{ST}}$ among localities without hierarchy is $0.117, P<0.001$

(b) L. hyperborea

\begin{tabular}{lccccc}
\hline Source of variation & Sum of & Variance & $\%$ & $\boldsymbol{F}$-statistic & $\boldsymbol{P}$ \\
& squares & components & variation & & \\
& & & & & \\
\hline Among regions & 455.7 & 0.284 & 10.1 & $F_{\mathrm{CT}}=0.101$ & $<0.001$ \\
& & & & & \\
\hline
\end{tabular}

This article is protected by copyright. All rights reserved. 


\begin{tabular}{lcccc}
\hline Among localities within & 56.6 & 0.023 & 0.8 & $F_{\mathrm{SC}}=0.009<0.001$ \\
regions & & & & \\
Within localities & 5131.5 & 2.511 & 89.1 & \\
& & & & \\
Total & 5643.4 & 2.818 & & \\
& & & & \\
\end{tabular}

Global $F_{\mathrm{ST}}$ among localities without hierarchy is $0.109, P<0.001$

Table 4 Analysis of molecular variance (AMOVA) of sites grouped by locality for each region of (a) Laminaria digitata and (b) Laminaria hyperborea

\section{(a) L. digitata}

\begin{tabular}{|c|c|c|c|c|c|}
\hline Source of variation & $\begin{array}{l}\text { Sum of } \\
\text { squares }\end{array}$ & $\begin{array}{c}\text { Variance } \\
\text { components }\end{array}$ & $\begin{array}{c}\% \\
\text { variation }\end{array}$ & $F$-statistic & $P$ \\
\hline \multicolumn{6}{|c|}{ Within St Malo Bay (Global $F_{\mathrm{ST}}$ among sites without hierarchy is $0.050, P<0.001$ ) } \\
\hline - Among localities & 23.2 & -0.006 & -0.3 & $F_{\mathrm{CT}}=-0.003$ & 0.648 \\
\hline - Among sites within & 11.2 & 0.116 & 5.3 & $F_{\mathrm{SC}}=0.052$ & $<0.001$ \\
\hline \multicolumn{6}{|l|}{ localities } \\
\hline - Within sites & 672.7 & 2.089 & 95.0 & & \\
\hline - Total & 707.1 & 2.199 & & & \\
\hline
\end{tabular}

Within Morlaix Bay (Global $F_{\mathrm{ST}}$ among sites without hierarchy is $0.020, P<0.001$ )

This article is protected by copyright. All rights reserved. 


\begin{tabular}{|c|c|c|c|c|c|}
\hline - Among localities & 29.3 & 0.052 & 1.8 & $F_{\mathrm{CT}}=0.018$ & $<0.001$ \\
\hline - Among sites within & 6.9 & 0.008 & 0.3 & $F_{\mathrm{SC}}=0.003$ & 0.201 \\
\hline \multicolumn{6}{|l|}{ localities } \\
\hline - Within sites & 1393.8 & 2.895 & 98.0 & & \\
\hline - Total & 1430.0 & 2.955 & & & \\
\hline \multicolumn{6}{|c|}{ Within Iroise Sea (Global $F_{\mathrm{ST}}$ among sites without hierarchy is $0.022, P<0.001$ ) } \\
\hline - Among localities & 32.8 & 0.066 & 1.9 & $F_{\mathrm{CT}}=0.019$ & $<0.001$ \\
\hline - Among sites within & 7.7 & 0.008 & 0.2 & $F_{\mathrm{SC}}=0.003$ & 0.330 \\
\hline \multicolumn{6}{|l|}{ localities } \\
\hline - Within sites & 1436.6 & 3.310 & 97.8 & & \\
\hline - Total & 1477.2 & 3.384 & & & \\
\hline \multicolumn{6}{|c|}{ Within Southern Brittany (Global $F_{\mathrm{ST}}$ among sites without hierarchy is $0.042, P<0.001$ ) } \\
\hline - Among localities & 13.9 & 0.090 & 3.1 & $F_{\mathrm{CT}}=0.031$ & 0.007 \\
\hline - Among sites within & 5.9 & 0.034 & 1.2 & $F_{\mathrm{SC}}=0.012$ & 0.009 \\
\hline \multicolumn{6}{|l|}{ localities } \\
\hline - Within sites & 743.6 & 2.811 & 95.8 & & \\
\hline - Total & 763.3 & 2.935 & & & \\
\hline
\end{tabular}

(b) L. hyperborea

\begin{tabular}{llllll}
\hline Source of variation & Sum of & Variance & $\%$ & $F$-statistic & $P$
\end{tabular}

This article is protected by copyright. All rights reserved. 


\begin{tabular}{|c|c|c|c|c|c|}
\hline & squares & components & variatio & & \\
\hline \multicolumn{6}{|c|}{ Within St Malo Bay (Global $F_{\mathrm{ST}}$ among sites without hierarchy is $0.016, P<0.001$ ) } \\
\hline - Among localities & 14.0 & 0.026 & 1.2 & $F_{\mathrm{CT}}=0.012$ & 0.018 \\
\hline - Among sites within & 5.4 & 0.007 & 0.4 & $F_{\mathrm{SC}}=0.004$ & 0.239 \\
\hline \multicolumn{6}{|l|}{ localities } \\
\hline - Within sites & 1005.4 & 2.052 & 98.4 & & \\
\hline - Total & 1024.8 & 2.085 & & & \\
\hline \multicolumn{6}{|c|}{ Within Morlaix Bay (Global $F_{\mathrm{ST}}$ among sites without hierarchy is $0.001, P=0.362$ ) } \\
\hline - Among localities & 10.3 & 0.010 & 0.4 & $F_{\mathrm{CT}}=0.004$ & 0.035 \\
\hline - Among sites within & 4.0 & -0.006 & -0.2 & $F_{\mathrm{SC}}=-0.002$ & 0.928 \\
\hline \multicolumn{6}{|l|}{ localities } \\
\hline - Within sites & 1556.6 & 2.655 & 99.9 & & \\
\hline - Total & 1570.9 & 2.659 & & & \\
\hline \multicolumn{6}{|c|}{ Within Iroise Sea (Global $F_{\mathrm{ST}}$ among sites without hierarchy is $0.010, P<0.001$ ) } \\
\hline - Among localities & 17.9 & 0.023 & 0.9 & $F_{\mathrm{CT}}=0.009$ & 0.007 \\
\hline - Among sites within & 5.9 & 0.003 & 0.1 & $F_{\mathrm{SC}}=0.001$ & 0.369 \\
\hline \multicolumn{6}{|l|}{ localities } \\
\hline - Within sites & 1437.0 & 2.684 & 99.0 & & \\
\hline - Total & 1460.7 & & & & \\
\hline
\end{tabular}

This article is protected by copyright. All rights reserved. 
Within Southern Brittany (Global $F_{\mathrm{ST}}$ among sites without hierarchy is $0.013, P<0.001$ )

- Among localities

- Among sites within

localities

- Within sites

- Total
14.5

2.8

0.002

1123.5

1140.9
1.2

$F_{\mathrm{CT}}=0.012$

0.016

$0.1 \quad F_{\mathrm{SC}}=0.001$

0.449

$\sqrt{2}$

1123.5

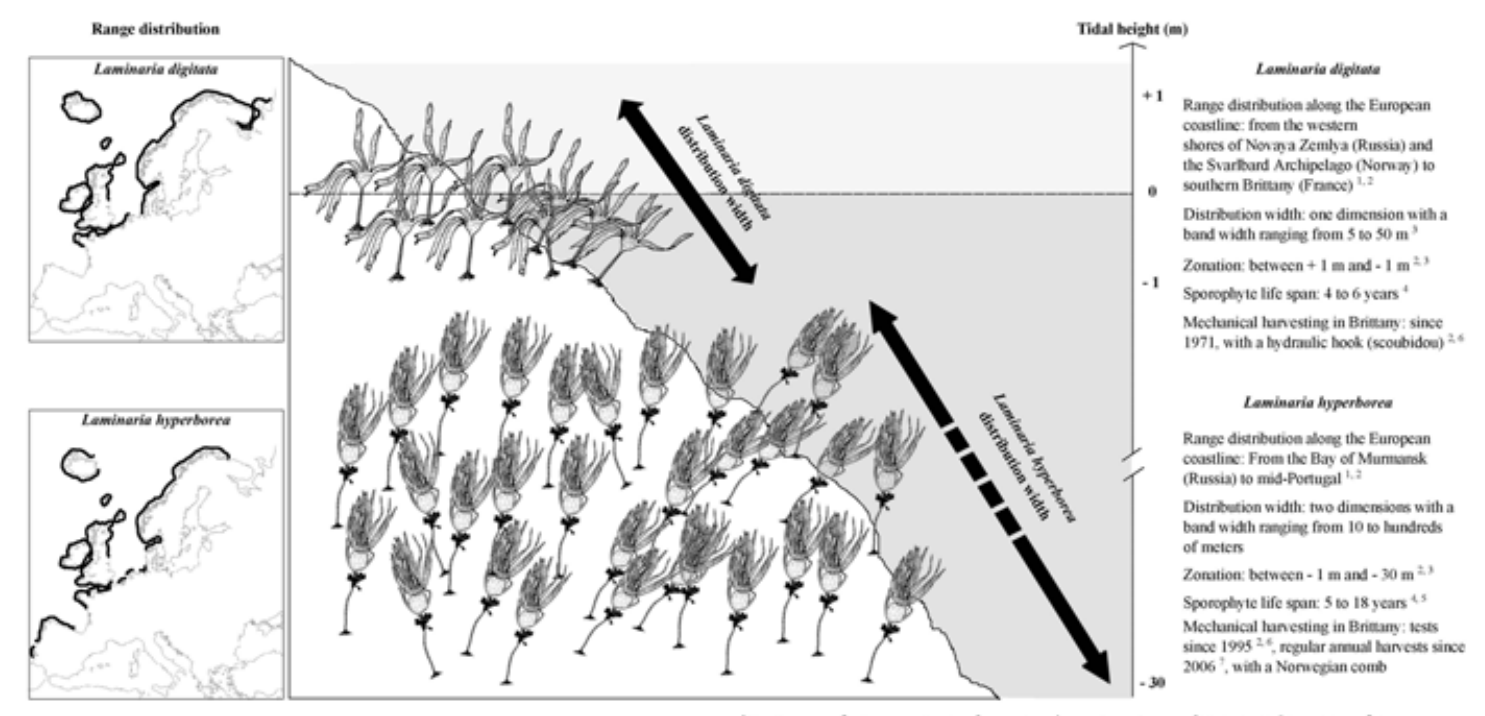

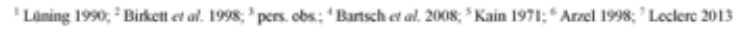

This article is protected by copyright. All rights reserved. 
(a)
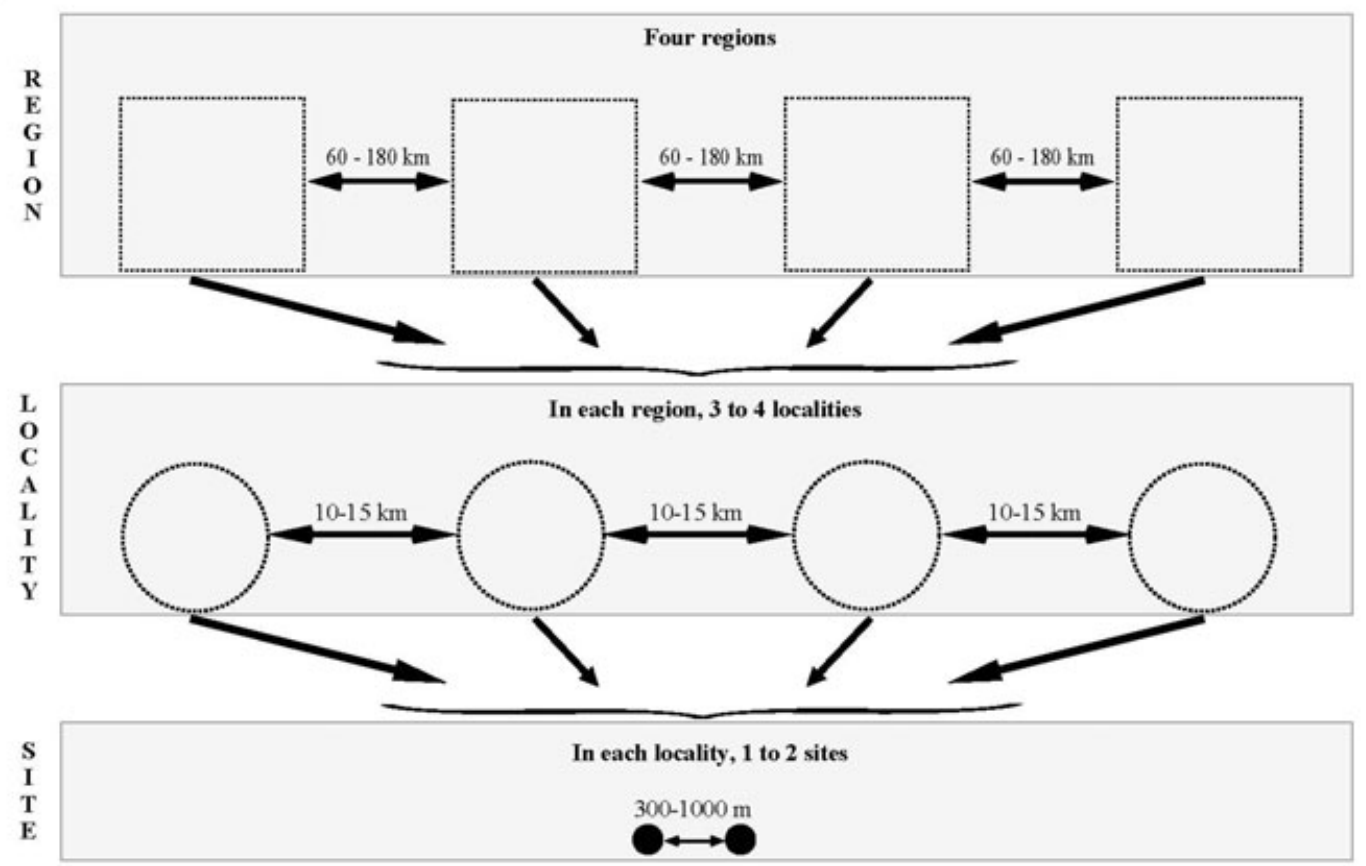

(b)
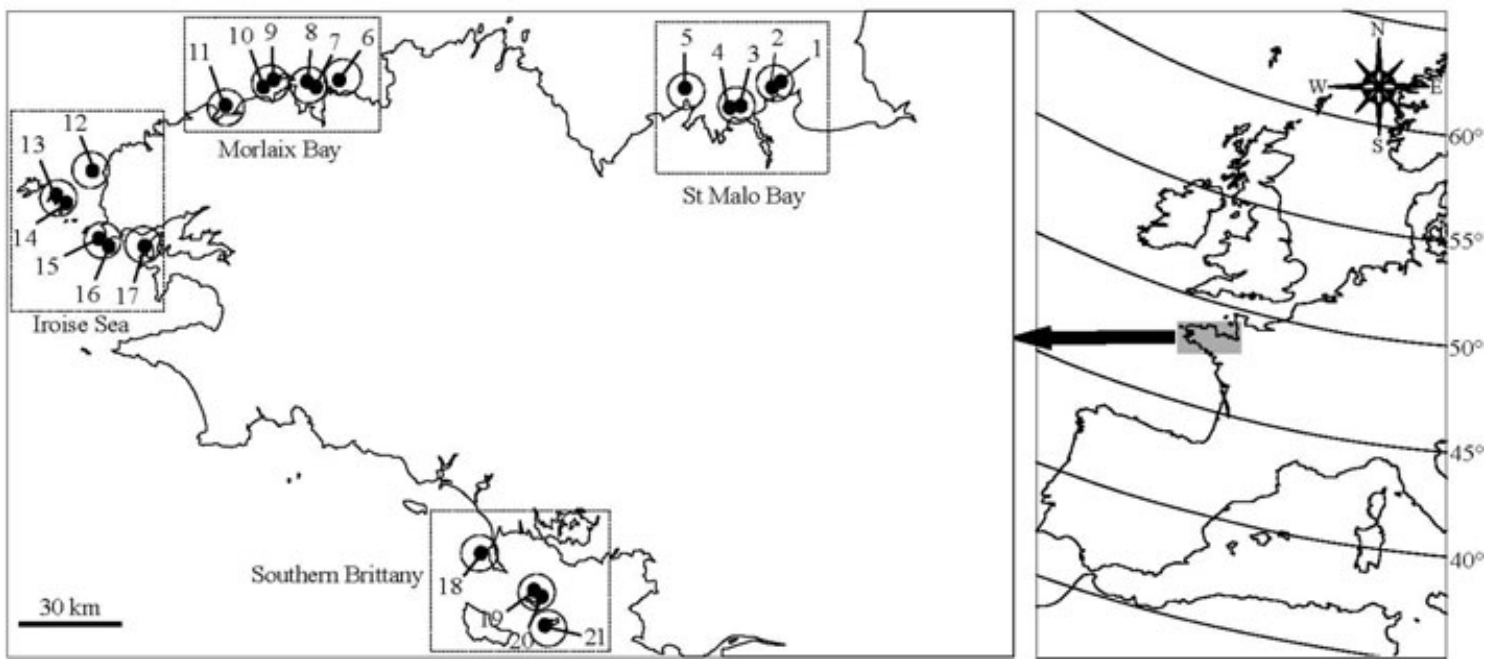

This article is protected by copyright. All rights reserved. 

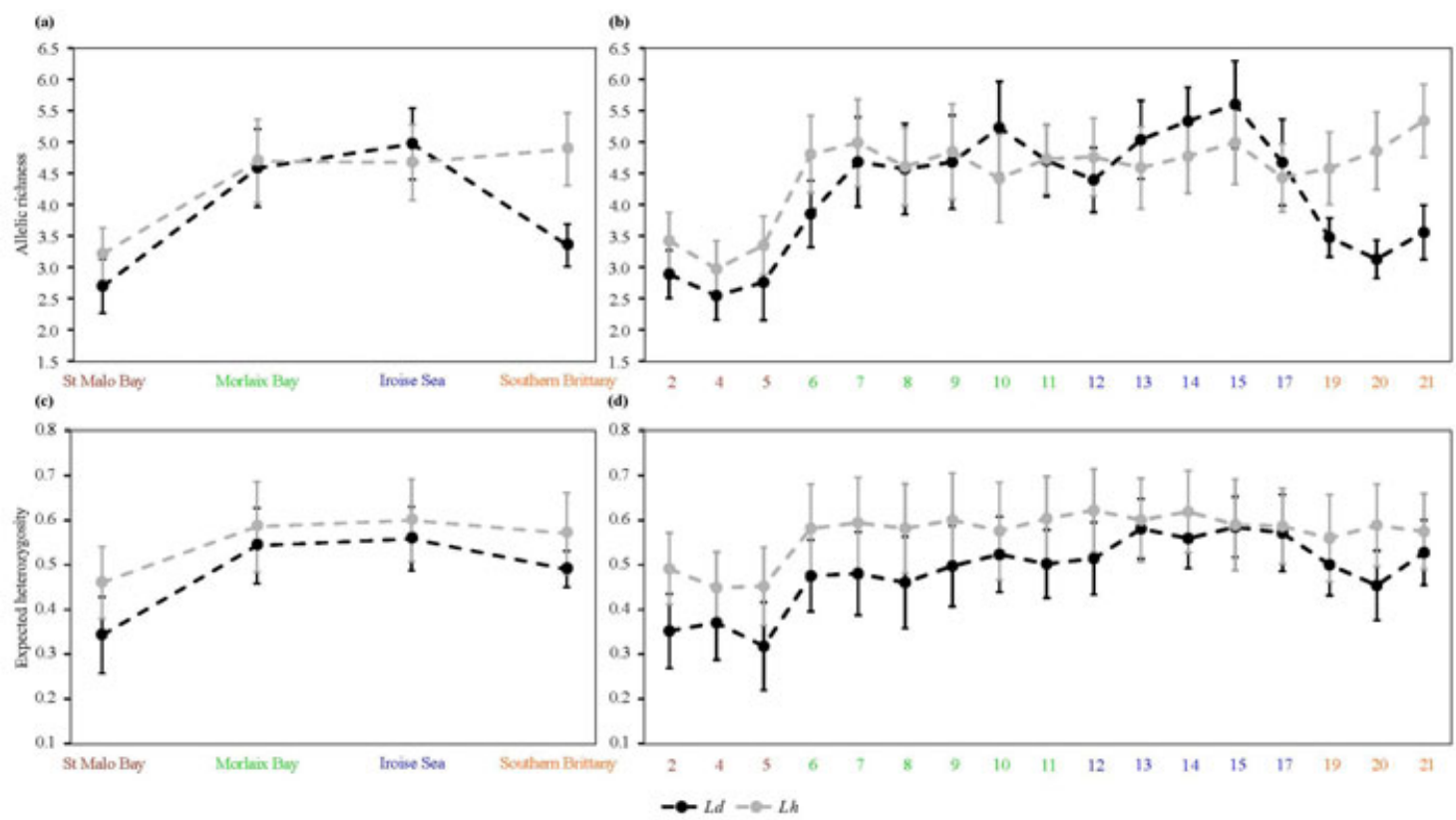

This article is protected by copyright. All rights reserved. 
(a) Laminaria digitata

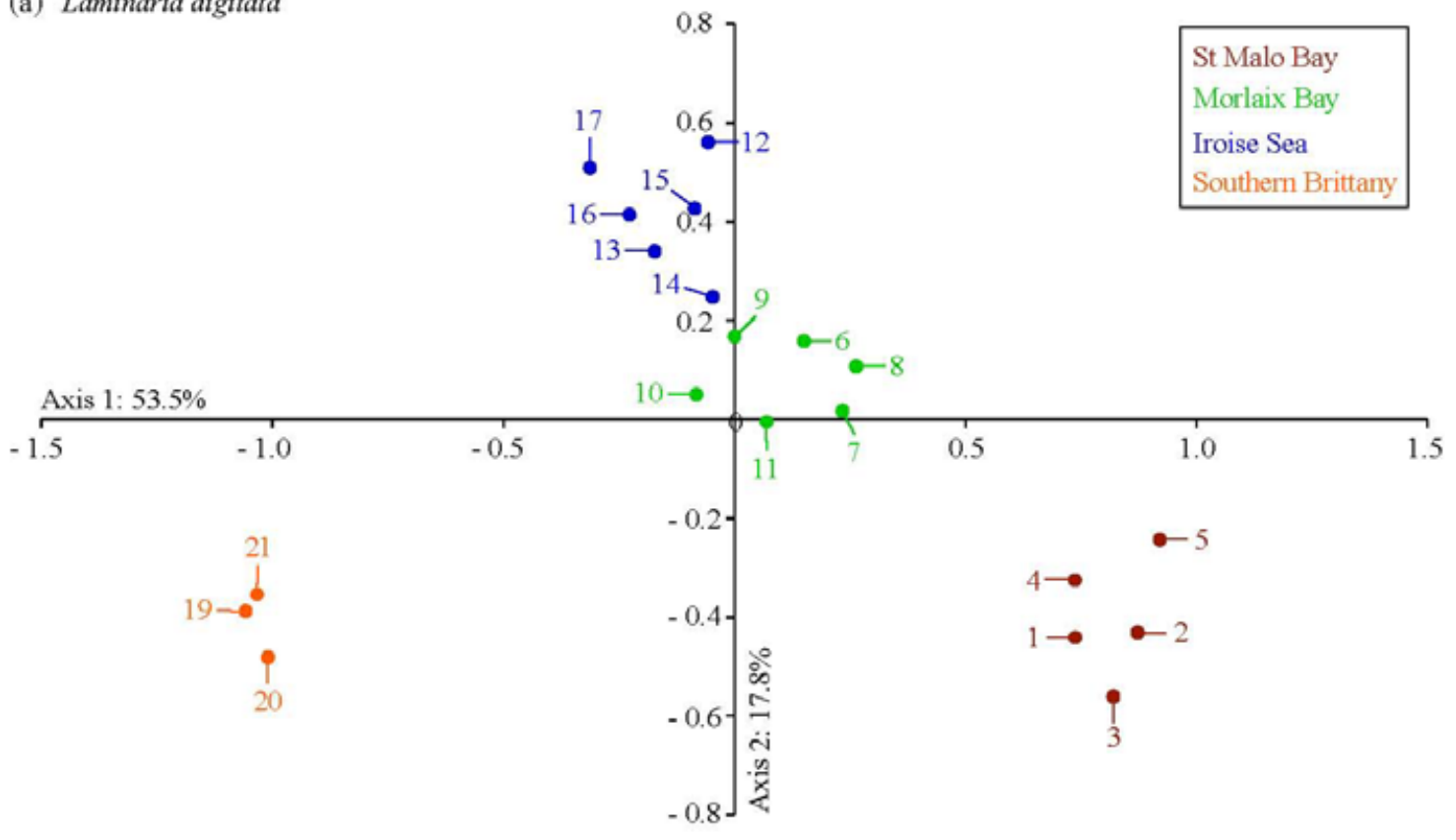

(b) Laminaria hyperborea

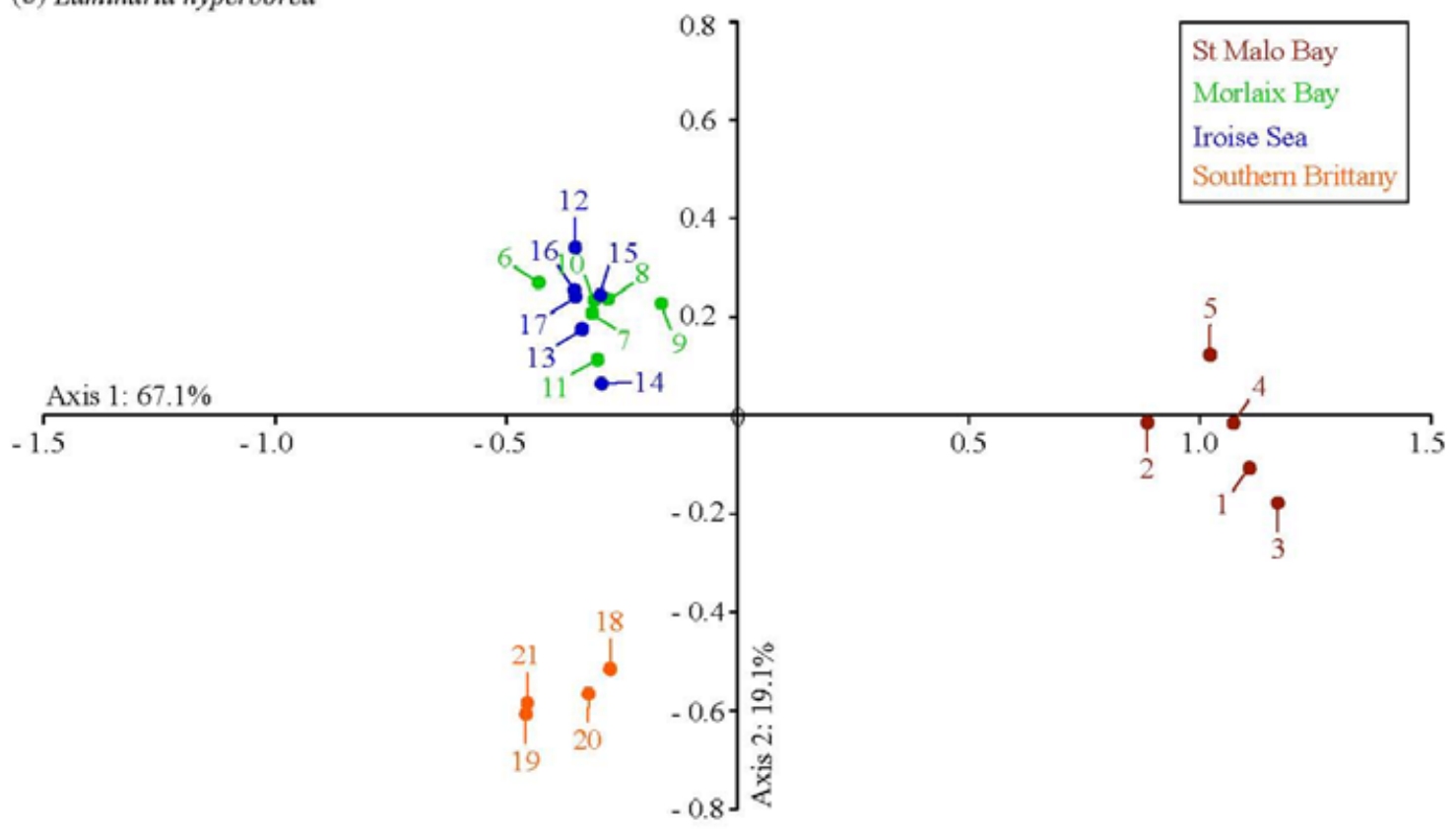

This article is protected by copyright. All rights reserved. 

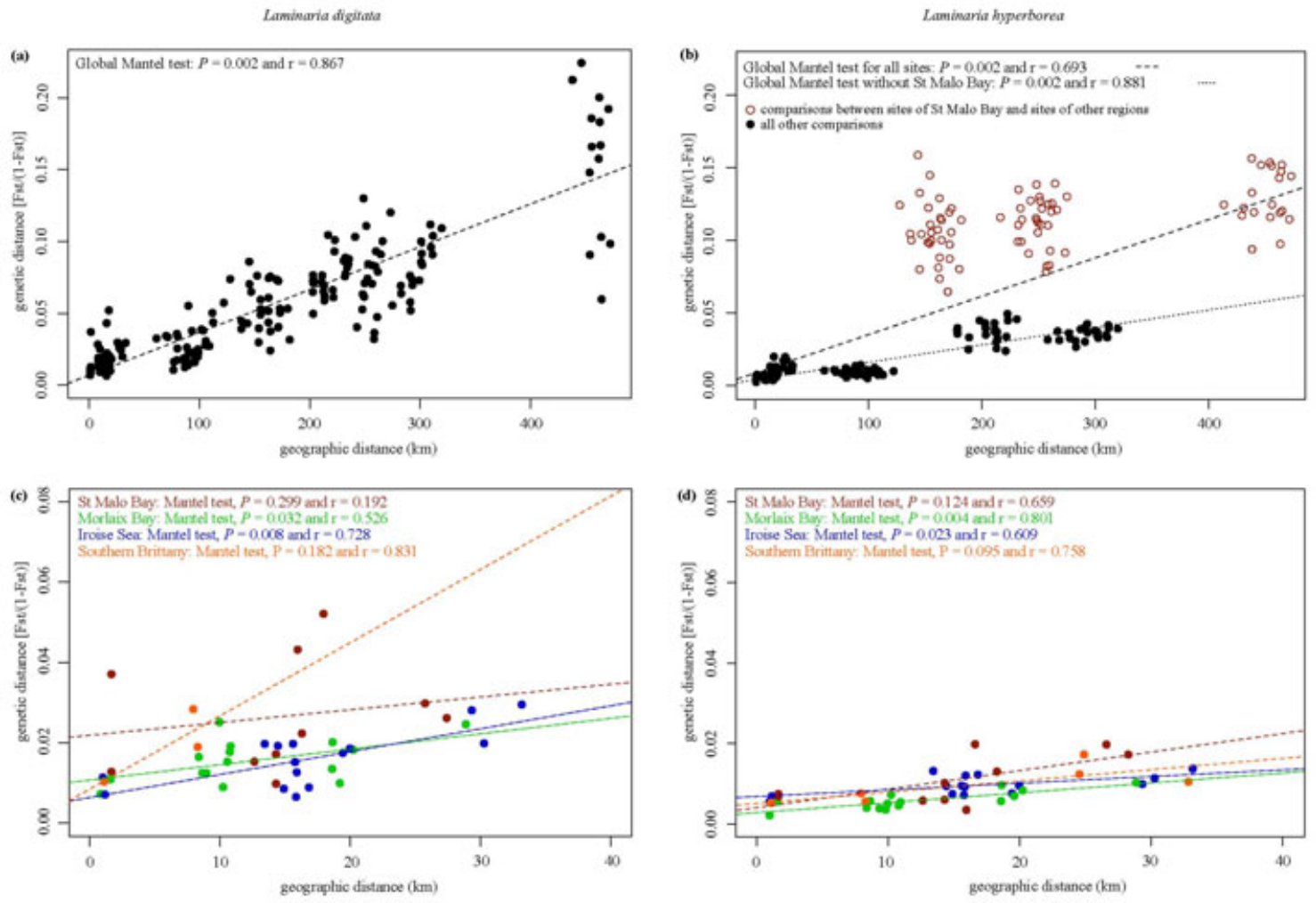

This article is protected by copyright. All rights reserved. 